\title{
Gênero, Sexualidade e Ensino de Histórias nas vozes de adolescentes
}

\author{
Gender, Sexuality and Education stories in the voices of \\ adolescents
}

\section{Luana Pagano Peres Molina ${ }^{1}$}

RESUMO

Buscamos compreender, por meio das narrativas coletadas de adolescentes entre 14 a 17 anos, questões referentes às construções e dinâmicas das relações de gênero e sexualidade e se o ensino de história permite a possibilidade de reflexão e discussão destas temáticas no ambiente escolar.

Palavras-chave: Sexualidade. Ensino de Histórias. Adolescente.

\section{ABSTRACT}

We seek to understand, through the narratives collected from adolescents aged 14-17 years, issues relating to construction and dynamics of gender relations and sexuality and the teaching of history allows for the possibility of reflection and discussion of these issues in the school environment.

Keyword: Sexuality. Teaching of history. Adolescent.

\section{Introdução}

Os corpos somente são o que são na cultura. Sendo assim, os significados de suas marcas não apenas deslizam e escapam, mas são também múltiplos e mutantes.

Louro (2003) 
Ficamos a interpretar e reinventar o mundo diante das variações do cotidiano, reelaborando e ressignificando conceitos e hábitos. Novas ideias surgem e as tecnologias se movimentam em múltiplas direções simultaneamente, acarretando transformações a cada segundo, o que nos permite uma dimensão ampliada à sexualidade, devido a multiplicidade de modelos e construções subjetivas.

A compreensão de que as formas de ver o mundo são desenvolvidas a partir das experiências sociais presentes na construção das subjetividades, ou seja, identidades individuais e coletivas, nos possibilita refletir sobre em quais condições, as relações de gênero e a construção da sexualidade se inscrevem em diferentes fazeres docentes e discentes nos cotidianos escolares.

Entende-se que o ser humano, ao longo de todo seu desenvolvimento, partilha de grandes potencialidades que serão traçados e delineados por uma complexa rede de sentimentos, sentidos, apropriações e produções. A partir da historiografia da Nova História, foram incluídos temas que até então estavam de fora do âmbito do interesse dos historiadores: diferentes expressões do cotidiano vivido por diferentes sujeitos, na sua diversidade de classe, étnica, de gênero, entre outros. Ou seja, nas mais diferentes esferas da vida humana e entre os mais diferentes sujeitos.

Segundo o historiador Peter Burke (1991), em seu livro "A Escola dos Annales", esse movimento trouxe consigo mudanças em relação às fontes históricas, que não mais se concentravam em documentos da esfera política, mas sim, ampliando suas fontes e seus métodos, trazendo novos sujeitos históricos, nas esferas políticas, sociais e culturais. Está lógica está envolta de diferentes modos de escrever a História, técnicas, temas de investigação, assim como diferentes conclusões.

A partir deste contexto os estudos históricos passam a vivenciar o multiculturalismo e nos apoiando nestas novas teorias buscamos a construção de caminhos para uma educação mais justa, no sentido da compreensão e da valorização da diversidade humana em suas múltiplas dimensões.

Por isso, trabalhar questões referentes às relações de gênero e sexualidade é ter a possibilidade de problematizar os espaços sociais, como por exemplo, na cultura/vivência escolar, abrangendo a multiplicidade e a pluralidade dos sujeitos a fim de perceber tensões e conflitos que envolvem essa construção histórico-cultural; acerca da inclusão e exclusão de pessoas, conhecimentos, discursos, práticas e políticas educacionais.

A diversidade se tensiona, instiga e inquieta; se percebida no âmbito de um processo dialógico, pode se revelar pedagógica [...] novas possibilidades de encontros, formas de (re)conhecimento e sensibilidades, bem como oportunidades para desmitificar o que 
imaginamos acerca de nós mesmos, dos outros e do mundo. É inestimável o que a diversidade pode nos proporcionar ao nos fazer avançar criticamente, sobretudo em relação a nós mesmos, a nossos valores, significados, representações (e autorepresentações, geralmente tão encantadas e generosas), limites, silêncios e possibilidades (DINIS, 2008).

A identidade de gênero está intrinsecamente ligado à sexualidade, de forma que as atividades sexuais ocorrem seguindo as particularidades das pessoas frente às exigências culturais, normas e padrões da sociedade. Segundo Werebe, devido à intervenção dos fatores ideológicos na sexualidade humana, não podemos caracterizá-la fora de seu contexto sóciocultural:

"Todo indivíduo nasce num momento dado da história, no seio de uma cultura distinta. Seus desejos, suas emoções e relações interpessoais são formados pelas suas interações com a cultura, dentro da sociedade em que vive" (WEREBE , 1998, p. 15).

A sexualidade foi e continua a ser construída histórica e culturalmente ao longo do tempo, inserida em um contexto social específico, regido por normas e regras comportamentais.

Todas essas transformações acabam por afetar as formas de viver e construir as identidades de gênero. Guacira Lopes Louro (1999) pontua que a sexualidade é construída e aprendida num processo ao longo de toda vida, de diferentes modos e sujeitos, por meio dos diversos processos culturais, que irá produzir e transformar a simbologia do corpo, e envolvendo-lhe em um sentido social.

Assim, as identidades de gênero serão compostas e definidas por relações sociais e redes de poder de determinada sociedade. A aceitação ou admissão de uma nova identidade sexual ou a transformação desta, torna-se uma alteração essencial que atinge diretamente a essência humana.

[...] Através de processos culturais, definimos o que é - ou não - natural; Produzimos e transformamos a natureza e a biologia e, consequentemente, as tornamos históricas. Os corpos ganham sentidos socialmente. A inscrição dos gêneros - feminino ou masculino - no corpo é feita, sempre no contexto de uma determinada cultura, portanto, com as marcas dessa cultura. As possibilidades da sexualidade - das formas de expressar os desejos e prazeres - também são sempre socialmente estabelecidas e codificadas. As identidades de gênero e sexuais, são, portanto, compostas e definidas por relações sociais, elas são moldadas pelas redes de poder de uma sociedade [...] (LOURO, 1999, p. 11-12). 
Aqui o corpo, será o próprio indivíduo, e seu valor está fortemente agregado às posturas e aparências em torno da classe social, raça, religião, etc. Será na sociedade, principalmente a atual, que o corpo torna-se uma referência para a noção de identidade de gênero, sexual ou biológica, dentro das mais diversas imposições culturais, num âmbito dentro da estética e ações morais e sexuais.

A sexualidade atualmente deixou de ser apenas um aspecto biológico de procriação para tornar-se cultural, portanto, diferentes culturas têm suas próprias normas, crenças e valores que vão compondo a dimensão humana. As regras sexuais são diferentes para ambos os sexos, sendo geralmente a maioria das restrições ligada ao gênero feminino, determinado pela cultura que impõem quais são as práticas sexuais apropriadas ou não.

As questões da sexualidade, na cultura ocidental, por muito tempo, foram motivos de tabus, devido suas posturas repressoras por parte da sociedade, diante dos comportamentos e conceitos em torno do sexo. Assim estes tabus foram manipulados de varias formas, ora como pecado, ora como fator de controle político da sociedade e em algumas vezes, até como instrumento de prazer e felicidade. No caso do Brasil, foi no período entre 1920 e 1930, que a Educação Sexual começou a apontar, como cuidado das mulheres e evitar atitudes femininas consideradas imorais e garantir o ato sexual como reprodução. Como trabalha Mary Neide Figueiró em estudos referente à Educação Sexual:

Partimos do pressuposto que a sexualidade, é sobretudo, uma construção sócio-cultural e, portanto, não estática, mas sim histórica e mutável. Acreditamos que em todo processo de interação professor alunos, alunos- alunos, e escola - família, por exemplo, dá-se a construção, manutenção ou a ressignificação dos valores morais, das normas sexuais e de todos os significados relacionados às questões da sexualidade (FIGUEIRÓ, 2003, p. 1-2).

Todos nós somos educados sexualmente ao longo de toda nossa vida, desta forma, esta pesquisa tem o intuito de trabalhar com adolescentes, uma vez que a fase da "adolescência", está marcada pelas transformações nas varias dimensões psicossociais e culturais, onde o jovem busca e confronta sua identidade pessoal, sexual e social.

É nessa fase da vida que fica mais visível, a incorporação dos modelos de masculinidade e feminilidade. E é neste contexto que se forjam as relações sociais entre os sexos, ou seja, as relações de gênero, que vão dar forma e significado às atitudes e práticas como homem ou mulher, suas interações sexuais, ideias e representações sobre a sexualidade e identidade sexual. 
A sexualidade é um dos importantes aspectos da adolescência, muito enfatizado não apenas pelos dados já apontados, mas também por que é nessa fase da vida do ser humano que a identidade sexual está se formando. A partir da ideia de Knobel (1992) o nascimento de uma criança em nossa sociedade, a família já começa a diferenciá-la sexualmente através de roupas, cores, brinquedos e objetos. Os pais sutilmente se encarregam de ir impondo, durante a infância, as diferenças entre meninos e meninas e a sociedade trata de acentuálas mediante elementos meramente externos.

Cano e Ferriani (2000) apontam que as mudanças físicas correlacionadas com as mudanças psicológicas levam o adolescente a uma nova relação com os pais e com o mundo, mas isto só será possível se o adolescente puder elaborar lentamente os vários lutos pelos quais passa, ou seja, o da perda do corpo infantil, a perda dos pais na infância e a perda da identidade infantil. Quando o adolescente vive todo esse processo, ele se inclui no mundo com um novo corpo já maduro e uma imagem corporal formada, que muda sua identidade, e é esta a grande função da adolescência, a busca da identidade que ocupa grande parte de sua energia.

Além disso, relaciona-se a importância das discussões referentes à sexualidade e adolescência, pois:

[...] cada vez mais, a sexualidade tem sido tema de discussão e debate não apenas na sociedade brasileira e sua importância fica ainda mais pronunciada quando controvérsias sobre o aborto, os direitos das minorias sexuais e, mais recentemente, a alarmante propagação da AIDS se colocaram no centro das atenções pública na vida contemporânea. (PARKER, 1991, p. 295).

Portanto, nosso intuito não é julgar os adolescentes que fazem parte do corpo documental deste trabalho, mas sim compreender o que fazem e sob qual entendimento o fazem.

No ensino de história entenderíamos que esta disciplina não seria somente uma "narração" do passado, mas o professor/historiador seria capaz de fazer uma análise dos acontecimentos traçando ligações entre as várias temporalidades e propiciando o entendimento de seus desdobramentos no presente. No caso dos estudos de gênero e sexualidade, o ensino de história abriria uma ponte para desconstruir conceitos e abranger o entendimento da construção histórica-social nos diferentes períodos e culturas referentes à estes temas. 
França (2009) diz que é necessário entender o papel do Ensino de História no processo de desvendamento dos problemas sociais, uma vez que este requer diálogo com os diferentes saberes, que são elaborados em diversos níveis e locais.

Assim, poderíamos dizer que a História a priori teria a finalidade de nos fazer compreender a própria historicidade na qual estamos envolvidos e também nos ajuda a enxergar a condição de sujeito histórico e transformador do contexto social que vivemos. $\mathrm{O}$ educador não pode abster-se do seu papel em relação às questões de aprendizagem da sexualidade humana e suas implicações sociais; pois é ele que detém os meios pedagógicos mais acessíveis e necessários para uma intervenção sistemática sobre a sexualidade, de modo a proporcionar a formação de opiniões mais críticas sobre o assunto.

\section{A escola e o cotidiano escolar}

A instituição escolar em seu cotidiano compartilha de possibilidades para desenvolver nos alunos um processo dinâmico, cheio de transformação, em que o eu e o outro mantêm uma interação dialética de construção e reconstrução de conceitos, simbolismos e experiências pessoais na sua identidade e cultura.

A escola é o espaço por excelência da transformação, mas também pode ser o espaço por excelência da ordem e do conservadorismo.

Dentro do cotidiano escolar se encontram as relações de gênero e da própria sexualidade, já que entendemos que as noções de sexualidade são inerentes ao ser humano. Kely Cristina Pereira (2007) pontua que ao integrar questões referentes à sexualidade em trabalhos pedagógicos, estamos buscando melhor qualidade de vida, semeando um futuro com esperança de dias melhores para os adolescentes e suas famílias, em diferentes contextos. Bem como contribuindo como somatório do arcabouço na saúde mental, sexual e reprodutivo desses autores. Entende-se o conhecimento como alavanca de uma reflexão critica para a conscientização e ação, facilitando a travessia e o alargamento dos horizontes sexuais, como dimensão de vida.

Esse modelo teórico-metodológico carrega em si a importância do diálogo e a problematização que devem ser recriados de modo que a educação libertadora se ajuste às condições de cada novo cenário, fundamentando-se numa concepção hermenêutica do conhecimento.

$\mathrm{Na}$ concepção problematizadora, o educador-educando aparecem como indivíduos integrados na comunidade, trabalhando não somente na questão intelectual, mas também 
no desenvolvimento como cidadãos, de forma a instigar, criticar, refletir e transformar (FREIRE, 2005).

Dentro desta perspectiva de uma educação democrática há atualmente políticas educacionais para inclusão de temáticas sobre grupos minoritários, como por exemplo, as tratadas pelos temas transversais nos PCNs ou os programas estaduais do Paraná, como o Programa Saúde nas Escolas (PSE), proposto pelo Ministério da Saúde em parceria com o Ministério da Educação, desenvolvido em todos os Estados da federação, fundamentando-se na abordagem de assuntos pertinentes à prevenção de DST, HIV e Aids, da gravidez na adolescência, do uso indevido de drogas e também relacionados às relações entre os gêneros e à diversidade sexual no espaço escolar. (PARANÁ, 2013).

Porém, também entendemos que a instituição escolar ainda se mantém engessada pela sua lógica de funcionamento e ideológica sobre indivíduos cristãos, heterossexuais e brancos.

Nilson Dinis em seu trabalho Educação, relações de gênero e diversidade sexual, explicita que à responsabilidade da discussão sobre essas temáticas é uma forma de reivindicar espaços nos currículos escolares frente aos novos sujeitos escolares. Pontuando que termos como alteridade, heterogeneidade, diferença, diversidade e multiculturalismo são algumas das expressões utilizadas ultimamente para expressar os debates na área da educação sobre estes novos movimentos sociais. (DINIS, 2008).

Ainda segundo este autor, vivemos um momento histórico em que se discuti sobre educar para a diferença, dentro de um contexto político mundial de intolerância e dificuldades generalizada em nos libertarmos de formas padronizadas de concebermos nossa relação com o outro. (DINIS, 2008, p. 479).

Para Dinis (2008, p. 489),

Ao apontar a construção histórico-cultural das identidades sexuais e de gênero, o/a professor/a pode auxiliar o/a educanda/o a descobrir os limites e possibilidades impostos a cada indivíduo quando se submete aos estereótipos que são atribuídos a uma identidade sexual e de gênero.

Dessa forma, assim como pontua Diniz, vale ressaltar que um novo exercício pedagógico é um possível convite a reinventarmos nossas relações com os outros e com nós mesmos, "nós desprendermos de nós mesmos, liberar a vida aí onde ela está aprisionada, devir-outro, tornarmos outra coisa" (DINIS, 2008, p. 489). 
O que caracteriza o universo escolar é a relação entre as culturas, relação essa atravessada por tensões e conflitos. Isso se acentua quando as culturas crítica, acadêmica, social e institucional, profundamente articuladas, tornam-se hegemônicas e tendem a ser absolutizadas em detrimento da cultura experiencial, que, por sua vez, possui profundas raízes socioculturais. Em vez de preservar uma tradição monocultural, a escola está sendo chamada a lidar com a pluralidade de culturas, reconhecer os diferentes sujeitos socioculturais presentes em seu contexto, abrir espaços para a manifestação e valorização das diferenças.

No caso desta pesquisa, o Colégio em que aplicamos o instrumento de conhecimento prévio, chama-se Colégio Estadual Antônio Raminelli, no bairro Jardim Ana Rosa, da cidade de Cambé e pertencente ao Núcleo de Educação de Londrina. O colégio possui ensino fundamental II e ensino médio sendo considerado uma escola de porte médio, está sitiada na zona periférica da cidade, e o público atendido pertence basicamente à classe baixa.

Seu funcionamento e atividades teve início no ano letivo de 1982, com um corpo docente formado por professores contratados por serviços extraordinários, sua inauguração foi em 29/04/1982 com o nome de Escola Estadual Antônio Raminelli - Ensino de $1^{\circ}$ grau, através da Autorização de Funcionamento Resolução Conjunta n. ${ }^{\circ} 37 / 82$ de 13/04/1982, publicada no D. O. E. em 25/05/1982 que autorizou a escola a funcionar pelo prazo de um ano com as séries iniciais do $1^{\circ}$ grau, sendo estendidas no ano seguinte ao atendimento até a $8^{a}$ série. Em 1992 implantou, de forma gradativa o ensino de $2^{\circ}$ grau no período noturno, que teve seu reconhecimento somente em 1999. (PARANÁ, 2012).

Este estabelecimento de ensino tem como uma das finalidades, a oferta de escolarização de crianças e jovens que buscam dar continuidade a seus estudos no Ensino Fundamental ou Médio, assegurando-lhes oportunidades apropriadas, considerando suas características, interesses, condições de vida e de trabalho, mediante ações didático-pedagógicas coletivas e/ou individuais.

A seguir apresentamos os resultados de nossa investigação realizada em três turmas do $1^{\circ}$. Ano e dois 2os. Anos do Ensino Médio do período matutino do Colégio Estadual Antônio Raminelli, em Cambé.

\section{Outros olhares: o perfil dos alunos}

As turmas analisadas responderam a um instrumento de aviso prévio, como forma de coleta de dados, com caráter exploratório acerca do tema. O instrumento constitui-se de um total de 20 questões, sendo divididos basicamente em quatro partes. A princípio era para ser 
trabalhado com 100 questionários, mas ao total foram trabalhados com 87 alunos levando em consideração as ausências durante as duas aplicações dos instrumentos investigativos.

Nas 5 primeiras perguntas fizemos questões que tencionam mapear e realizar uma caracterização do perfil sócio cultural do aluno, como idade, religião, renda familiar, se o adolescente vive com pai e mãe, se tem irmãos e quantos são. Aqui essa pergunta torna-se interessante, porque caso tiverem irmãos mais velhos, possuem um referencial de comportamentos, gostos, maneiras, próprios das relações entre irmãos, que influência também na incorporação de modelos masculinos e femininos. E, por fim, se os pais trabalham fora, onde eles costumam ir após as aulas (no intuito de saber se trabalham) e se vão para casa com quem costumam ficar (como por exemplo, sozinhos, com avós e ou irmãos).

Já na segunda e terceira parte deste questionário as perguntas são voltadas para investigar sobre a vivência da sexualidade (aqui, esse termo esta empregado na abrangência desta palavra, como explicado no primeiro capítulo) buscando perceber se já possuíram algum tipo de educação sexual (na escola, na família ou na igreja), se na suas casas eles possuem algum espaço para diálogos referente à sexualidade, quem é a pessoa que eles mais conversam sobre sexo, de onde eles recebem maiores informações sobre a sexualidade e qual a idade que eles acreditam ser ideal para começar a vida sexual.

No terceiro momento, sobre as relações entre gênero, o questionário busca investigar se eles acreditam que ainda há discriminação contras as mulheres, se no âmbito escolar ou familiar, ainda existam brincadeiras só para meninos e outras só para as meninas, se na aula de educação física existam esportes que só os meninos devem praticar, incluindo se essas aulas deveriam ser mistas ou separadas e por fim, se no grupinho deles, entre amigos, existam mais meninas ou meninos.

E por fim, questões para mapear se há possibilidade do ensino de história levantar debates e discussões referentes as relações de gênero e sexualidade, assim como se na escola há algum tipo de preconceito e enfrentamento sobre as diferentes formas de vivenciar sua sexualidade e para finalizar, se os jovens acreditam que o espaço escolar seja um ambiente propício para debater questões de gênero e sexualidade.

Para a análise das narrativas dos alunos presentes na nossa investigação tomamos como referência as considerações de Regina Célia Alegro que afirma:

Assim, para o ensino de História, mais do que para qualquer outra disciplina ensinada na escola básica, é necessário considerar os "diferentes discursos", os diferentes conteúdos que circulam na sala de aula. Para além do conhecimento veiculado no livro didático, na fala do professor, na tradição oral e nos meios de comunicação de massa, é 
possivel reconhecer, também, o conhecimento elaborado pelo aprendiz. [...] a partir do conhecimento prévio manifesto pelos estudantes. O que o aluno já sabe, o conhecimento prévio (conceitos, proposições, princípios, fatos, idéias, imagens, símbolos), é fundamental para a teoria da aprendizagem significativa, uma vez que constitui-se como determinante do processo de aprendizagem, pois é significativo por definição, base para a transformação dos significados lógicos dos materiais de aprendizagem, potencialmente significativos, em significados psicológicos [...]. (ALEGRO, 2008, p. 187).

Para a autora, extremamente importante também nas aulas de história é a "reinterpretação" dos conceitos que produzem e expressam a modificação da estrutura cognitiva. Por isso, a importância atribuída aos conhecimentos e competências já existentes na estrutura cognitiva do sujeito que aprende é tão destacada quanto a linguagem e a estrutura conceitual de diferentes corpos de conhecimento objetos de aprendizagem.

Neste sentido fica claro que é através do conhecimento prévio, levados em consideração a partir dos questionários aplicados juntos aos alunos, poderemos perceber se houve ou não aprendizagem ao comparar aprendizagens anteriores e posteriores.

Nesta mesma direção de abordagem, também nos deteremos nas narrativas ${ }^{2}$ produzidas pelos alunos tomando como postura analisar em seu conteúdo aquilo que Arminda Ferreira, Celeste Dinis, Eduarda Leite e Fátima Chaves chamam a atenção. Segundo as autoras,

Os alunos não absorvem tudo o que os manuais e professores lhes dizem que é historicamente significante. Pelo contrário, filtram informação, lembram ou esquecem, adicionam ou modificam, reconstruindo as suas estruturas de compreensão através de seus valores, idéias e disposições. (MELLO, 2001, p. 157).

Assim, temos como resultado, para as autoras, que o processo pode ser encarado como a expressão dos contextos e das estruturas que subjazem à atribuição de significância histórica. Deste modo, parte das nossas tarefas pedagógicas deve ser ajudar os alunos a expô-las já que muitas das vezes estão submersas.

Ainda para as autoras, para que os alunos expressem as suas narrativas sobre as ações passadas, eles têm que "pôr-se na pele de" um personagem, envolvendo-se num processo de

2 A questão da narrativa histórica, ou da volta da narrativa ao campo da história, teve seu ápice no Brasil, durante a década de 1990 e autores como Lawrence Stone, E. Hobsbawm e Roger Chartier produziram grandes debates. O conceito de narrativa que aqui utilizamos baseia-se em Lawrence Stone (1991) e em Hobsbawm (1998) que concluem que, na verdade, a narrativa nunca tinha desaparecido da história e daí questionarem o retorno da mesma à disciplina. 0 que se postulava naquele momento era a volta da narrativa em outros termos enfatizando outros sujeitos e outros enfoques. A partir desses autores consideramos que a narrativa sempre esteve presente na escrita da história. O que parece novo, e discutimos em nosso trabalho, é a possibilidade de produções narrativas pelos alunos da educação básica. 
empatia histórica, levando-os a identificarem-se diversamente e com diferentes graus, com os agentes, acontecimentos ou instituições. Lembrando-se de Peter Lee, as autoras reafirmam que nesta relação empática com as personagens do passado, os alunos fazem-no através de lentes da sua contemporaneidade, atitude a que ele chamou de "presentismo" (MELLO, 2001, p. 157). Também levamos em consideração a metodologia utilizada por Arminda Ferreira (e outras) na análise das narrativas dos alunos. Segundo as autoras, devese atentar para aquilo que denominam de "significância" nas narrativas dos alunos, definida por elas como "uma determinante textual" e não apenas uma mera transcrição da fala. Para elas, é difícil definir o conceito, dado que é um termo polissêmico, que assume uma definição dependendo dos domínios de saber que dele se apropriam. Mas, sugerem como definição, aquela que é mais utilizada no campo da educação histórica:

\begin{abstract}
A atribuição de significância a uma determinada unidade de informação é determinada sempre por um contexto. Perante uma qualquer tarefa, os sujeitos têm intuições de significância que determinarão os critérios de atribuições de valores diferenciados. E esta atribuição depende sempre de efeitos contextuais, sendo que, quanto mais efeitos contextuais forem convocados, maior é a possibilidade de atribuição de significância que iremos dar a esta ou aquela unidade de informação. (MELLO, 2001, p. 156).
\end{abstract}

Ou seja, na análise das narrativas dos alunos é importante observarmos o que está subentendido nas mesmas a partir do contexto no qual eles estão inseridos como, por exemplo, suas vivências particulares. Levando em conta todas estas questões passaremos agora à análise dos nossos instrumentos aplicados.

\title{
As vozes da história: as narrativas dos alunos
}

Segundo Foucault (2002), os discursos exercem o seu próprio controle, através de procedimentos que funcionam, sobretudo a título de classificação, de ordenação, de distribuição, como se tratasse desta vez, de submeter outra dimensão do discurso: a do acontecimento e do acaso.

Foi com essa preocupação que procuramos analisar as falas dos alunos. Assim, percebemos que de um total de 87 questionários respondidos, $70 \%$ são do primeiro ano do ensino médio e $30 \%$ do segundo ano do ensino médio. Desta porcentagem, $47 \%$ são meninos e $53 \%$ são meninas, como analisamos no gráfico abaixo: 
Gráfico 1 - Porcentagem de alunos por gênero da amostra, 2011

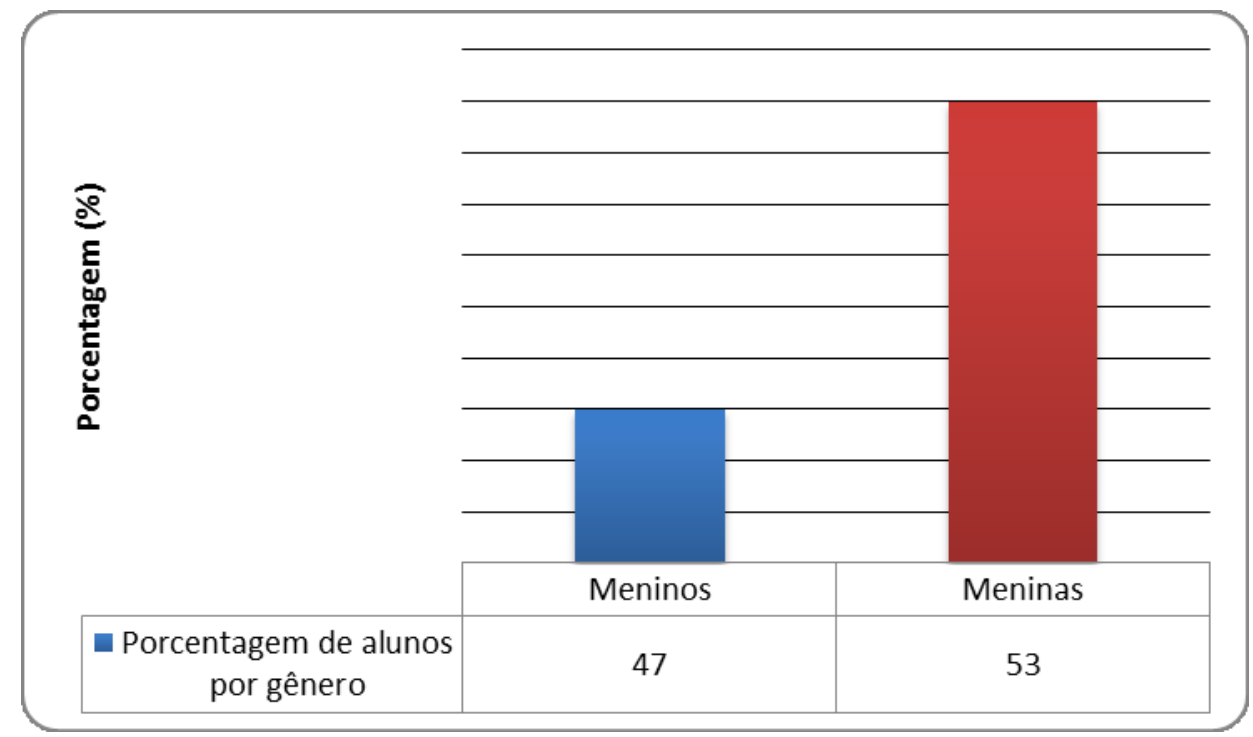

Fonte: Elaboração da autora, a partir do estudo de campo.

Gráfico 2 - Porcentagem de turmas da amostra, 2011

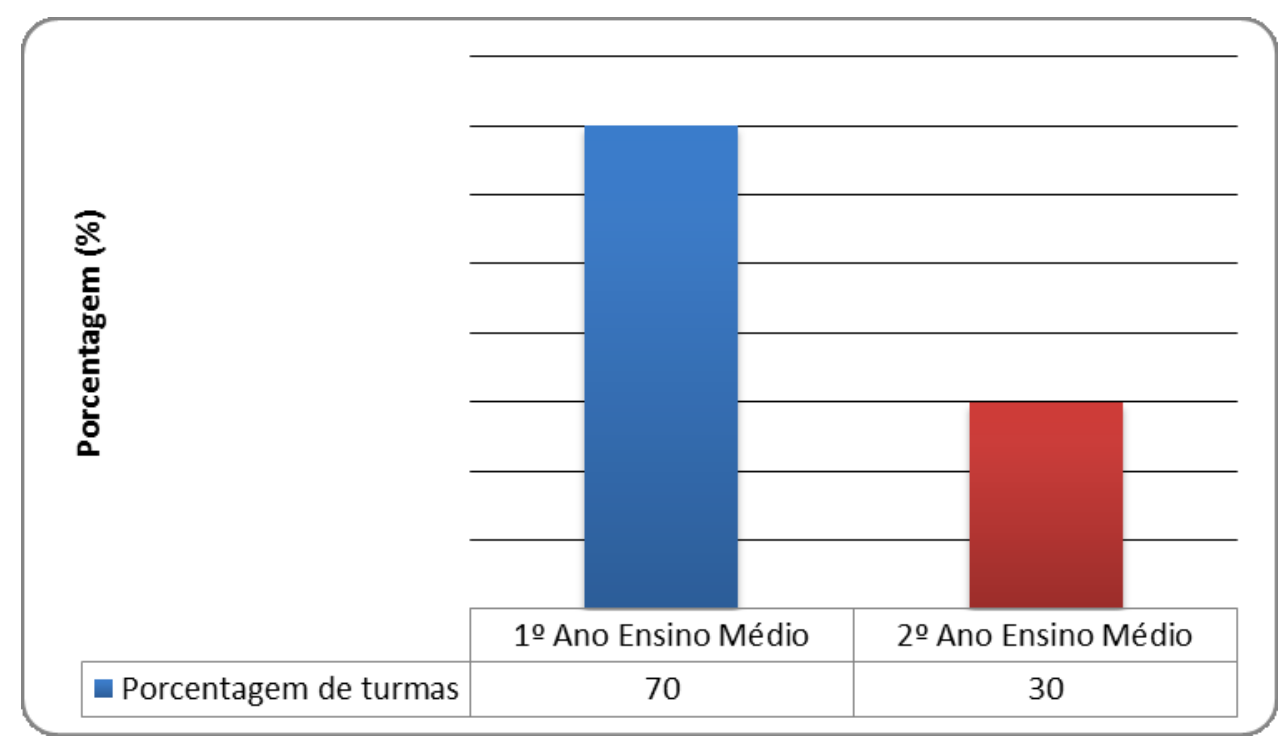

Fonte: Elaboração da autora, a partir do estudo de campo.

A faixa etária predominante está entre os 15 e 16 anos, que respectivamente representam $47 \%$ e $42 \%$; com 14 anos são $5 \%$ e 17 anos ou mais $6 \%$, conforme podemos visualizar nos gráficos a seguir: 
Gráfico 3 - Faixa etária dos (as) Alunos (as) da amostra, 2011

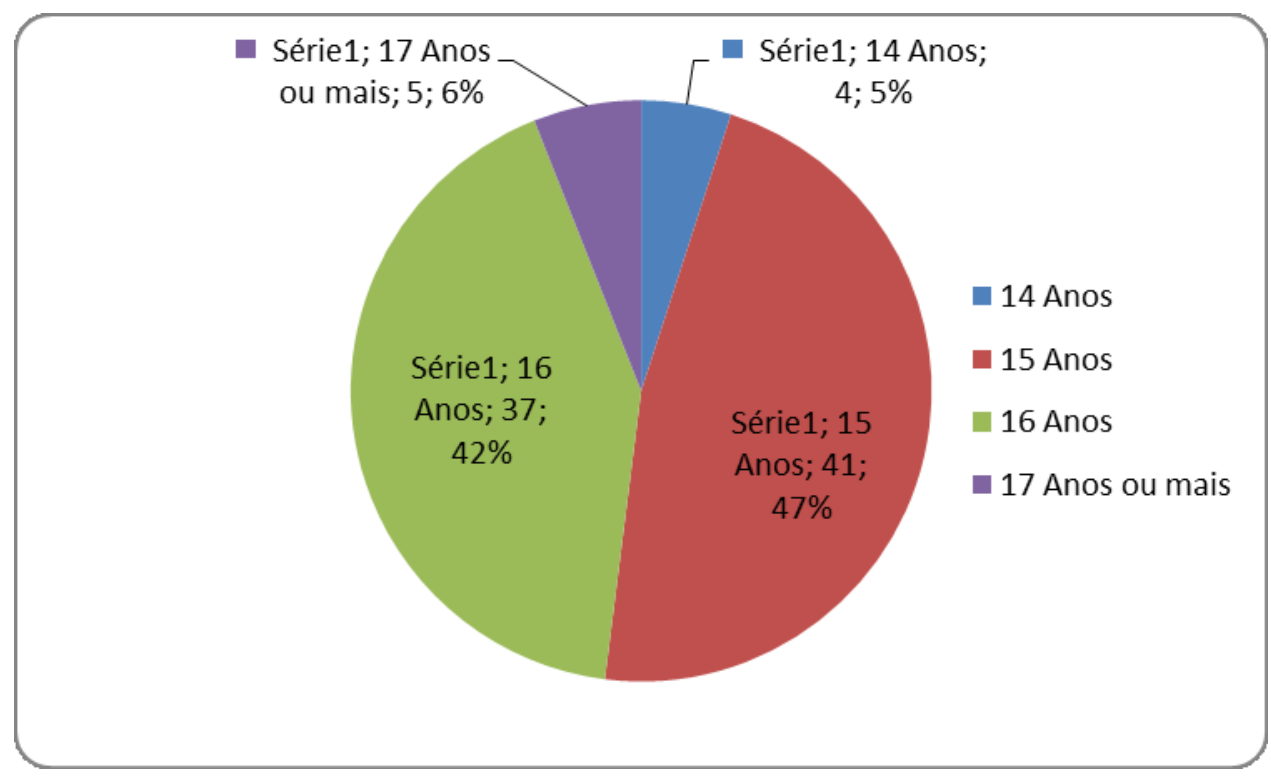

Fonte: Elaboração da autora, a partir do estudo de campo.

Considerando-se a importância de identificar o universo socioeconômico e cultural dos adolescentes, foi solicitado a eles alguns indicadores a respeito da renda de suas famílias. Segundo a Lei $\mathbf{n}^{\circ} 15.826$ - 01/05/2008, publicado no diário oficial da Assembléia Legislativa do Estado Paraná (PARANÁ, 2008), o piso mínimo salarial é de R\$622,00.

Assim, dos 87 questionários, $44 \%$ a família vivia com de 1 a 5 salários mínimos (R\$ 622,00 até $\mathrm{R} \$ 3.110,00$ ); $17 \%$ de 5 a 10 salários mínimos (aproximadamente de $\mathrm{R} \$ 3.110,00$ até $\mathrm{R}$ \$ 6.220,00); $2 \%$ acima de dez salários mínimos (acima de $\mathrm{R} \$ 6.220,00$ reais ao mês); $37 \%$ responderam que não sabiam. Portanto, a maioria dos adolescentes provém de famílias cuja faixa de renda varia de $R \$ 622,00$ a $R \$ 3.110,00$ reais ao mês.

Outro aspecto da constituição familiar, diz respeito à religião, que é predominantemente composta por católicos e evangélicos, sendo que, $49 \%$ dos jovens se denominaram Católicos; 35\% Evangélicos; 3\% responderam outros, como Ateu, Testemunha de Jeová ou Sud; e por fim, $13 \%$ não responderam a respeito de sua religião, no caso, ou não tendo ou optando por não revelar. Conforme analisamos nos gráficos a seguir: 
Gráfico 4 - Religião dos (as) Alunos (as) da amostra, 2011

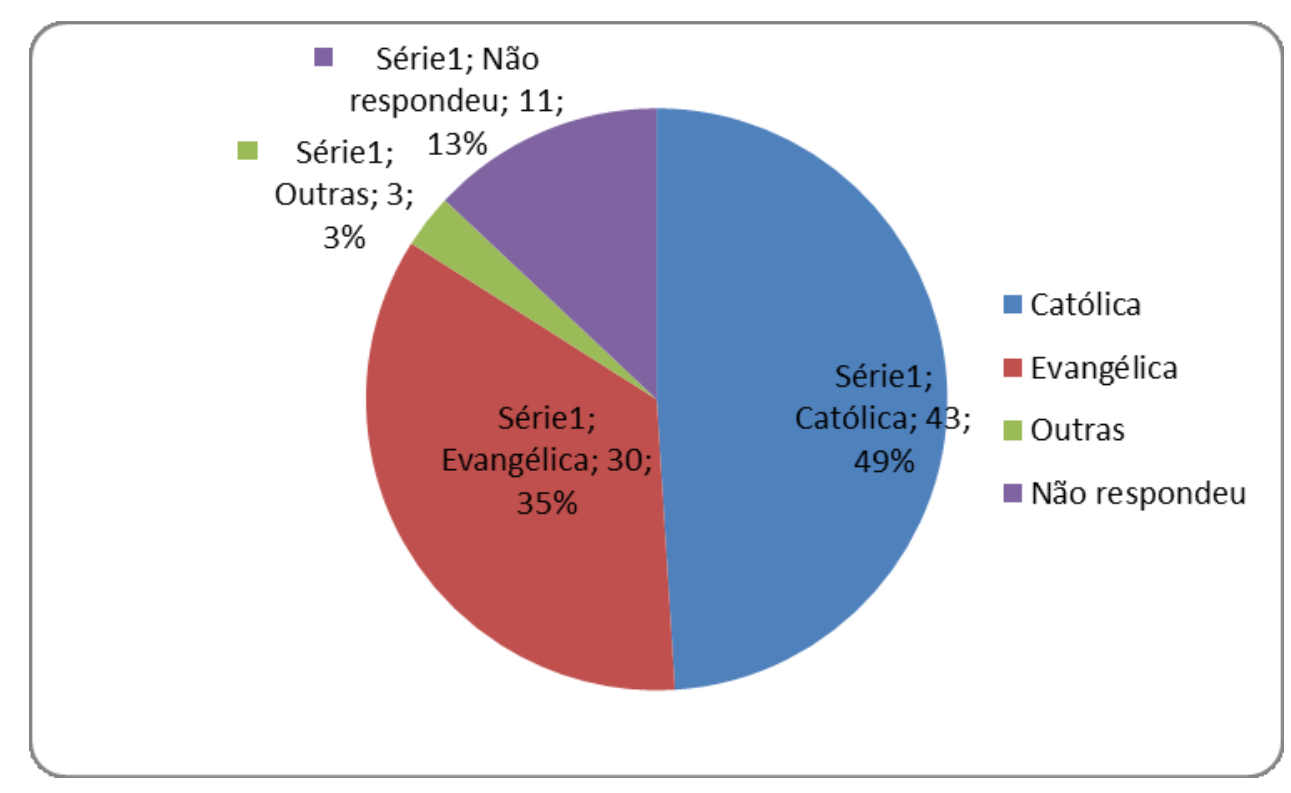

Fonte: Elaboração da autora, a partir do estudo de campo.

Quanto às ocupações dos pais desses adolescentes, 63\% tanto o pai quanto a mãe trabalham fora de casa; $24,5 \%$ somente o pai trabalha fora, ou seja, a mãe pode não trabalhar ou trabalhar em casa, como percebemos nessas falas:

"Meu pai trabalha fora, depois da escola vou para casa e fico com minha mãe"; "Meu pai trabalha fora, mas minha mãe não, vou para casa e fico com ela e com meu irmão", ou "Meu pai trabalha fora, minha mãe trabalha em casa, após as aulas vou para casa e fico com minha mãe".

Percebemos que apenas 3\% das mães trabalha fora, assim o pai pode não estar empregado ou trabalhar em casa; $2 \%$ nenhum dos dois trabalham; e apenas $7,5 \%$ dos jovens trabalham no período pós aula, sendo em sua maioria, ajuda aos pais no trabalho da família, como por exemplo:

"Sim, geralmente ajudo meu pai na loja de eletrônico e as vezes vou para casa e fico sozinha" ou "Trabalham, depois das aulas vou 'pra' casa e dia de segunda eu fico segunda, os outros dias eu trabalho à tarde com meus pais.". 
$\mathrm{Na}$ análise dos questionários frente ao universo familiar, constatou-se que predominantemente os jovens vivem com seus respectivos pais biológicos (pai e mãe); $12 \%$ vivem somente com a mãe, como nas seguintes falas:

\begin{abstract}
"Não, só com a minha mãe", "Só com minha mãe, meu padrasto e meu irmão mais velho" ou "Não, só com minha mãe, minha irmã e meu irmão"; $3 \%$ vivem somente com o pai, "Só com o meu pai, porque eles são separados, moramos eu, meus irmãos e meu pai." ou "Não com minha mãe biológica, mas com minha madrasta, com meu pai e irmão."
\end{abstract}

E 3\% vivem com avós/tios, sem a presença dos pais, "Com meus avós. Minha mãe está em Portugal e meu pai eu não conheço.".

Dos 87 questionários, 93\% dos jovens possuem irmãos, ou seja, referem-se à 81 jovens, sendo que 47 deles possuem irmãos mais velhos; $72 \%$ têm de um a dois irmãos e $28 \%$ acima de três irmãos. Outro dado é que $99 \%$ dos adolescentes não possuem filhos e $1 \%$ já vive a realidade da maternidade/paternidade.

Portanto, o perfil socioeconômico da maioria desses jovens é de pais que trabalham fora, com um ou mais irmãos, com doutrina religiosa católica ou protestante e possuindo uma renda que pode variar entre $R \$ 622,00$ a $R \$ 3.110,00$ reais ao mês.

Já na análise envolvendo diretamente questões das temáticas propostas a serem trabalhadas nesta dissertação, iniciamos buscando saber se estes adolescentes já possuíram algum tipo de educação sexual formal, na escola, na família, ou em alguma outra instituição, como por exemplo, a religiosa, entendendo que se esse fato já tivesse ocorrido, eles responderiam as questões sem tanto constrangimento, com mais naturalidade ou com mais clareza a cerca do assunto e principalmente tentando identificar o que é para eles a educação sexual. Com isso, $41 \%$ dos adolescentes responderam que não tiveram nenhum tipo de educação sexual; e 59\% disseram possuir ou terem possuído algum tipo educação sexual. 0 Interessante aqui é perceber que estes jovens, acreditam terem tido educação sexual, somente com algumas palestras disponibilizadas pela escola ou comunidade e principalmente as aulas de ciências, geralmente voltada a trabalhar a questão do aparelho reprodutor (somente com um caráter biológico), DSTs/AIDS e gravidez.

Como é visível em algumas falas:

"Mais durante a aula de biologia", "A professora de ciências da sexta série falou o primeiro bimestre inteiro sobre doenças sexualmente transmissíveis.", "Já tive na escola, mas era muito raramente" ou "Já 
tive, mas não com frequência", "Já tive, durante a aula de a professora tirou minhas dúvidas".

A ideia apresentada pelas respostas, como percebemos em alguns exemplos citados, é de que a educação sexual trabalhada com esses alunos foi de maneira informal, desarticulada, sem continuidade e sequer foi retomado posteriormente. Porém, em alguns casos, isto não ocorre:

\begin{abstract}
"Sim, a família comenta e de vez em quando professores dão alguns exemplos", "Minha mãe me dá muitos conselhos sobre isso", "Sim, na escola, e na minha família aprendi a diferenciar o certo o errado" ou "Na família sim, mas na escola diretamente relacionada a educação sexual não".
\end{abstract}

Nesses exemplos vemos que o diálogo ocorreu de maneira informal, fora do âmbito escolar e principalmente através de conversas, trocas de informações, com uma certa "liberdade" de ouvir e falar, o jovem aprecia essa experiência, como educação sexual. O que nos possibilita refletir que o próprio jovem apropria-se e reconhece o sentido da educação sexual como sendo um espaço em que ele pode se expressar, ter um diálogo, por meio da abertura dos professores e / ou dos pais sobre os assuntos que permeiam a sexualidade.

Na sequência, pergunto se há espaço para diálogos a respeito da sexualidade com a família, $28 \%$ falaram que não possuem diálogo algum em casa, enquanto $49 \%$ constataram que possuem esse espaço de conversa e $23 \%$ responderam que há diálogo, mas de maneira esporádica, como,

"Muito raro", "Meu pai não gosta muito", "De vez enquando (sic) quando o assunto é solicitado ou discutido", "Sim, há dialogo, mas não falamos muito disso, mais todos respeitam cada um."

E também foi muito comum encontrar algumas respostas, como:

"não é comum, mas tem", "muito raro" ou "Não digo espaço para diálogos, mas de vez enquando a gente conversa sobre esse assunto, sendo por acaso as vezes por alguma coisa que está passando na TV".

Aqueles que responderam haver diálogo entre eles e seus pais, somaram-se 
"Quando precisa falar, não tem problema nenhum em conversar sobre isso", "Sim, na minha casa nós somos abertos para qualquer assunto", "Sim, sempre houve", "Sim, é um assunto muito discutido".

Ou nos casos mais das meninas, percebemos que estas procuram mais o semblante da mãe, como: "Com a minha avó e minha mãe sim, com os outros não." "Com minha mãe, sim". Já nos casos em que não há nenhum diálogo, os jovens colocam: "Não, minha mãe tem um pensamento bem antigo", "Nunca cheguei a entrar no assunto", "Não falamos sobre isso", "Nunca tive vontade de conversar sobre isso".

Na pergunta que se refere sobre a pessoa que o jovem mais se sente à vontade para falar sobre sexualidade, a resposta foi predominantemente os amigos, devido a intimidade criada entre eles, como segredos, os gostos, a importância do sentimento de pertencimento por alguém que vá compreender você, como:

\begin{abstract}
"Meus amigos, porque é um assunto ao qual não teria coragem de falar diretamente com meus pais e nem eles comigo", "Amigos, pois é um assunto mais fácil e menos constrangedor de conversar com os amigos", "Um amigo", "Minhas amigas, porque com minha mãe não dá para conversar sobre esse assunto, já minhas amigas é um papo mais aberto, sem vergonha".
\end{abstract}

E até mesmo por essa questão de proximidade de idade, acreditar que estão passando pelas mesmas descobertas e situações, muitas vezes a conversa dentro da família, resume-se somente entre os primos e irmãos, "Minhas primas, por serem da mesma idade", "Com minha mãe (me sinto desconfortável), não gosto, prefiro conversar com minha irmã”, ou com a mãe por terem mais intimidade: "Minha mãe, porque ela sempre me orientou sobre sexo" ou "Minha mãe por ela ser mulher e ter mais intimidade comigo", diz uma jovem de 16 anos que encontra-se no segundo ano do ensino médio

O curioso é que muitos responderam não a pessoa que ele sente-se mais confortável e sim quem o deixa mais desconfortável e ai, a resposta predominou entre os pais (principalmente a figura do pai) e professores.

Essa pergunta foi uma das mais interessantes, por que além de se perceber como o sexo ainda é um tabu muito forte, mesmo na mentalidade e vivência do jovem percebemos também alguns preconceitos nas relações de gênero, principalmente entre a menina que não fala de maneira alguma com o pai sobre esse assunto, simplesmente porque ele é homem, assim muitas meninas responderam, 


\begin{abstract}
"Meu pai, como ele é homem acho que não entende muito, não tem o mesmo pensamento que eu", "Meu pai, pelo respeito que eu tenho com a vida privada dele, pela questão dele ser separado", "Meu pai, porque ele é homem e por isso, não me sinto a vontade de falar sobre isso com ele" e "Meu pai, porque tenho mais liberdade com minha mãe para falar desses assuntos".
\end{abstract}

Ou até é uma postura distanciada do próprio pai, quando nega-se a falar sobre isto com as filhas, por sentir-se desconfortável, "Meu pai, ele não gosta de falar sobre estas coisas comigo", diz uma menina de 15 anos do primeiro ano do ensino médio.

O fato de os adolescentes terem receio de conversar com os pais, ou os próprios pais não saberem lidar com essa temática, nos faz entender que o desconforto surgido nessa relação seria compreensível já que muitos desses pais não tiveram uma educação sexual aberta, com diálogos, reflexões, bombardeios na mídia através de programas e novelas, e até mesmo em canções, filmes, perpassando todo o cotidiano. Recebemos algumas respostas como,

\begin{abstract}
"Meu pai e minha mãe é desconfortável, tem certas opiniões deles que não batem com a minha", "Meu pai, porque ele ia falar um monte pra mim" "Meu pai, ele me acha muito nova para isso", "Com meus avós, porque quando estamos perguntando, fazem cara feia para responder tudo e dizem 'você ainda não tem idade para saber disso", "minha mãe, ela é sem cabeça", "com minha família, pois pelo fato de nunca falarmos disso dá sempre um pouco de vergonha", "com minha família, pois eu sinto vergonha", "com minha mãe, porque é meio embaraçoso".
\end{abstract}

Através desses exemplos, percebemos que o sentimento de vergonha perpassa tão intrinsecamente a construção da sexualidade na vida do individuo, inclusive em suas relações interpessoais. Portanto, ter que trabalhar sua sexualidade ou simplesmente conversar sobre ela, traz consigo sentimentos de certo mal-estar, timidez, incerteza, se devem ou não perguntar, e terem receio por não saberem se os pais responderam ou não as suas perguntas e como reagiram a elas.

Porém, vemos alguns casos em que os jovens não conversam com a figura paterna, mas possuem liberdade e diálogo com a mãe, como este caso: "Minha mãe, porque desde que comecei a sair é ela que me dá palestras toda vez que eu saio de casa”. Ainda alguns jovens, acreditam que não devemos conversar isso com ninguém, por serem situações íntimas: "desconforto com todos, por que sim, hoje em dia não se pode confiar em ninguém", diz uma jovem de 17 anos do segundo ano do ensino médio, que ao falar sobre o desconforto, dá a sensação de que tem algum medo de sofrer alguma represália, por confiar em alguém e descobrirem. Outros jovens responderam simplesmente "não falo sobre isso com ninguém", e "Com ninguém, porque eu não gosto, guardo para mim", diz esse garoto de 15 anos, do primeiro ano do ensino médio. Percebemos que nossos jovens reprimem suas angústias, 
dúvidas, possuem medo de viver e falar sobre sua sexualidade, seus sentimentos, ou seja, de tudo o que está descobrindo. Falta-lhe a chance de perceber e compreender a sexualidade como algo inerente ao individuo, com mais naturalidade, e que não há mal nenhum em conversar sobre isto com outras pessoas, inclusive sua pais, irmãos, professores, amigos, ou, qualquer um que lhe traga confiança.

Por fim, encontramos em pouquíssimos, mas existentes, casos em que o adolescente vê a discussão referente à sexualidade, como algo natural hoje em dia, por isso não acredita e não vê problema algum em se falar sobre isso,

\begin{abstract}
"Minha mãe é uma boa conselheira e amiga, não tem problemas ou dúvidas enquanto a isto", "Converso abertamente com qualquer pessoa com que convivo, porque hoje considero um assunto muito normal", "Não tenho problemas para falar sobre isso com qualquer pessoa, acho legal perceber como os outros pensam" diz uma jovem de 15 anos do primeiro.
\end{abstract}

Outros dizem: "É um assunto normal", "Me sinto confortável para falar com qualquer pessoa, porque é um assunto comum hoje em dia" e "não (há desconforto), porque você não deve se reprimir".

Já na questão seguinte, que indaga de onde eles recebem maiores informações sobre a sexualidade, passamos a analisar este gráfico:

Gráfico 5 - Meios de busca por informações dos (as) alunos (as) da amostra, 2011

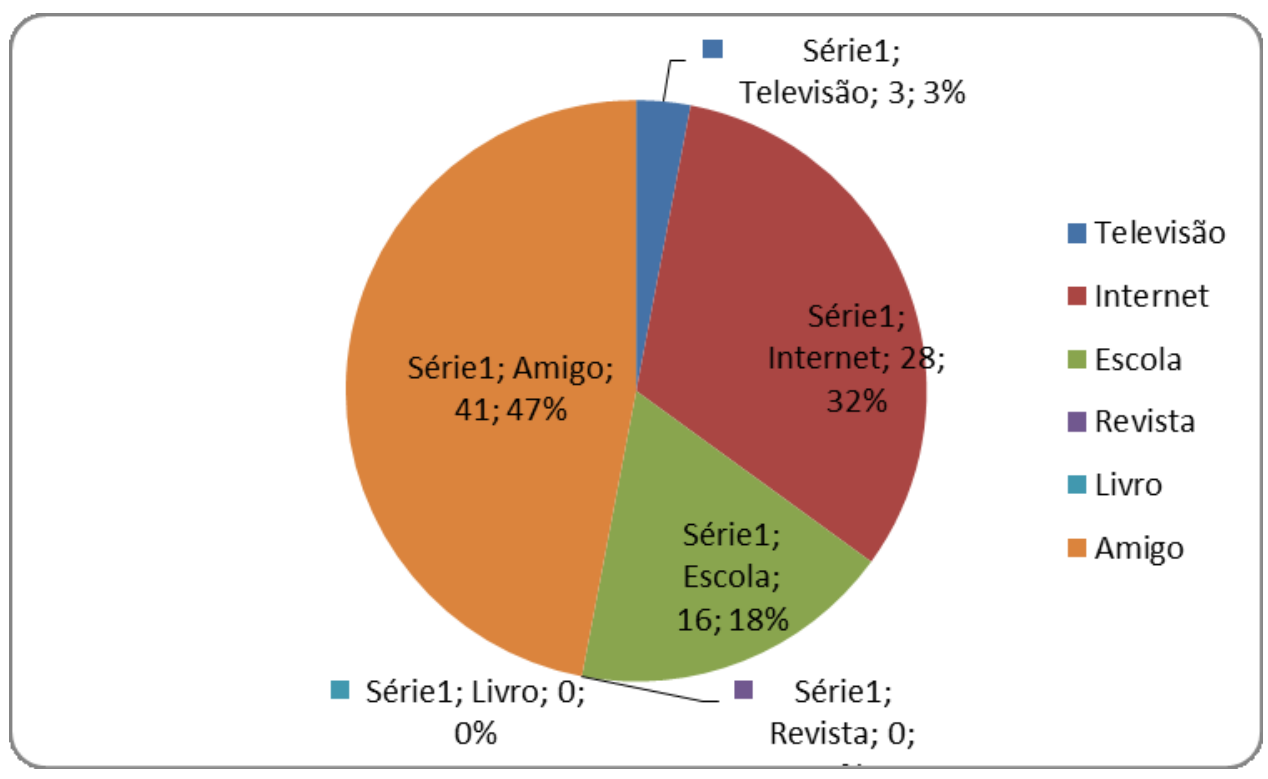

Fonte: Elaboração da autora, a partir do estudo de campo. 
Nesta questão os alunos poderiam assinalar mais de uma resposta, focalizando então os espaços em seu cotidiano que possuíam maior troca de informações sobre sexualidade, resultando assim, 47\% responderam os amigos, valorizando os diálogos e vivências entre eles, como uma das maiores fontes de troca de informações; $A$ internet aparece em segundo com $32 \%$, a escola com $18 \%$, a televisão com $3 \%$. Ressaltamos que é importante essa busca por informações, mas devemos ser críticos quanto às mesmas, perguntando-nos se essas informações são satisfatórias, suficientes e chegam aos adolescentes de maneira mais científica.

Sobre a indagação que se refere à idade ideal para iniciar a vida sexual, $43 \%$ determinaram uma idade de aproximadamente 17 anos para cima, como o momento "certo" para dar inicio a sua vida sexual. As justificativas surpreendem quando percebemos que a maior preocupação do jovem é a gravidez indesejada, eles acreditam que sendo maiores de idade, poderiam trabalhar e sustentar a criança e no caso dos meninos, a criança e a namora, caso tivessem algum "acidente", como vemos:

"Com 18 anos porque você já é maior de idade e já estará trabalhando e ganhando, caso surja frutos dessa relação", "Só aos 18, porque já vamos ter responsabilidade", "Aos 18, é quando a formação do corpo se completa", "18, por causa da maioridade", "18, porque já tenho mais responsabilidade", "Acho que quando você tiver mais responsabilidade, uns 18 anos, está bom", "17 anos, pois já somos mais maduros nessa idade", "18 pois você já é responsável pelos seus atos", um garoto de 15 anos diz, "18 anos, porque se faz filho, já está trabalhando para sustentar a criança".

Outro da mesma idade também, "Dos 20 anos em diante, porque caso haja um imprevisto você já terá uma vida financeira estável”, portanto, percebemos que os jovens estão preocupados em ter maturidade e principalmente responsabilidade para esse grande dilema da adolescência, têm a consciência da importância do ato sexual ocorrer no momento em que você esteja preparado fisicamente e psicologicamente, mas isso não significa que haja uma idade apropriada para isso, seguindo a linha desse pensamento, $37 \%$ dos adolescentes responderam que não há uma idade adequada e sim que vai depender muito do tipo de relacionamento, com quem está se relacionando e de pessoa para pessoa.

Assim, podemos perceber em algumas falas:

\footnotetext{
"Acho que não tem uma idade certa, você tem que estar ciente e seguro do que estiver fazendo", "Não sei, não existe uma idade específica, quando tiver que acontecer, acontece.", "vai da mentalidade da pessoa", "Não tem, por que depende da pessoa".
}

Uma garota de 14 anos responde: 


\begin{abstract}
"Na minha opinião não tem idade e sim o pensamento, do querer da pessoa", outra menina de 16 anos diz: "A idade que a pessoa preferir, que ela achar que está pronta pra isso, e se cuidar, saber que o que acontecer, seja gravidez ou uma doença, ela vai ter que arcar com as consequências."
\end{abstract}

Por ser uma temática que envolve muito as questões religiosas, a primeira vez para as mulheres é ligada à ideia de pureza, sinal de ser uma moça de "família", respeitosa. Para família, principalmente para o pai, a virgindade da menina é sinônimo de respeito e de honra, agora para os meninos, quanto antes começarem a se relacionarem e terem relações sexuais será melhor. Nos questionários 15,5\% responderam que relação sexual só após o casamento, tendo como principal justificativa as questões religiosas de cada um, como:

"[...] depois do casamento independente da idade"; uma garota evangélica de 17 anos responde: "depois do casamento, sigo questões religiosas"; assim como também um garoto evangélico de 15 anos: "Depois de casar, porque na Bíblia fala que sexo antes do casamento é "prostituição", nesse caso percebemos bem os valores e normas religiosas desse jovem.

Outro menino de 16 anos diz:"Depois do casamento porque a religião ensinou assim"; ou "Para mim, a vida sexual deve se iniciar após o casamento, pois é o correto [...]". Somente $4,5 \%$ dos adolescentes não se posicionaram a respeito, ou não respondendo a pergunta ou simplesmente respondendo que não sabiam.

Nas próximas questões, o questionário se coloca mais no intuito de instigar os adolescentes frente às relações de gênero. Portanto, na pergunta onze levantamos o questionamento sobre se eles sabiam definir o que era gênero e se caso soubessem deveriam explicar/justificar sua resposta: 
Quadro 1 - Definição de Gênero dos (as) alunos (as) da amostra, 2011

\begin{tabular}{|c|c|c|c|}
\hline $\begin{array}{c}\text { Você sabe o que é } \\
\text { Gênero? }\end{array}$ & Não responderam & Resposta negativa & Resposta afirmativa \\
\hline 87 questionários & $\begin{array}{c}7 \text { adolescentes não } \\
\text { responderam }\end{array}$ & $\begin{array}{l}\text { } 73 \text { adolescentes } \\
\text { responderam que não } \\
\text { Justificativas: } \\
\text { "Não sei explicar"; } \\
\text { "Não sei definir"; } \\
\text { "Não consigo definir” }\end{array}$ & $\begin{array}{c}7 \text { adolescentes } \\
\text { responderam que sim } \\
\text { Justificativas: } \\
\text { "Deve ser alguma } \\
\text { opção ou coisa } \\
\text { parecida"; } \\
\text { "Não sei explicar, mas } \\
\text { envolve o feminino e o } \\
\text { masculino"; } \\
\text { "Questões de } \\
\text { identificação social em } \\
\text { relação ao sexo" }\end{array}$ \\
\hline
\end{tabular}

Fonte: Elaboração da autora, a partir do estudo de campo.

Percebemos neste quadro a dificuldade que os jovens possuem de explicar o que realmente seja o conceito de gênero. Eles não conseguem definir, o que nos leva, a $84 \%$ da nossa fonte documental a relatar a falta de conhecimento ou informação correta sobre o que seja as relações de gênero. Mesmo aqueles que afirmam saber o que seja gênero, eles fogem da real formação do conceito. Ficamos atentos, a única resposta mais coerente a pergunta, de um jovem de 16 anos do segundo ano do ensino médio, que diz "Questões de identificação social em relação ao sexo", ampliando assim seu entendimento sobre as relações de gênero.

Ao serem questionados a respeito do preconceito frente a posição da mulher na sociedade, e se este preconceito ainda existe ou não, 2 não responderam e deixaram a resposta em branco, o restante dividiu-se assim: 
Quadro 2 - Existência da discriminação do gênero feminino de acordo com os (as) alunos (as) da amostra, 2011

\begin{tabular}{|c|c|c|}
\hline $\begin{array}{c}\text { Discriminação do gênero } \\
\text { feminino }\end{array}$ & Resposta negativa & Resposta afirmativa \\
\hline 87 questionários & $\begin{array}{c}15 \text { adolescentes responderam } \\
\text { que não } \\
\text { Justificativas: } \\
\text { "Não, eu acho que as mulheres } \\
\text { já foram aceitas por todos"; } \\
\text { "Não, as mulheres tem muito } \\
\text { espaço na sociedade"; } \\
\text { "Não, porque hoje a mulher é } \\
\text { livre para trabalhar fora e } \\
\text { temos uma mulher na } \\
\text { presidência" }\end{array}$ & $\begin{array}{c}70 \text { adolescentes responderam } \\
\text { que sim } \\
\text { Justificativas: } \\
\text { "Os homens ainda veem as } \\
\text { mulheres como sexo frágil"; } \\
\text { "As mulheres não possuem a } \\
\text { mesma liberdade para sair, } \\
\text { namorar e se divertir como os } \\
\text { homens"; } \\
\text { "Sim, a sociedade é muito } \\
\text { machista ainda" }\end{array}$ \\
\hline
\end{tabular}

Fonte: Elaboração da autora, a partir do estudo de campo.

Desses 70 adolescentes que afirmam que ainda há discriminação na sociedade com as mulheres, 34 são meninos e 36 são meninas; Para estes que acreditam que ainda haja preconceito não deram maiores desdobramento em suas respostas, ou "Sim, apesar de termos conquistado bastante espaço na sociedade", "Sim, principalmente no trânsito", coloca uma garota de 15 anos;

\footnotetext{
"Sim, pelo machismo que ainda existe", "Sim, muitos homens só querem usar as mulheres, mas isso acontece só porque muitas delas dão tal liberdade" ou "Sim, mais acho que em parte é culpa das mulheres na sua busca pelo reconhecimento, elas passaram dos limites para poderem ser comparadas aos homens" diz uma menina de 15 anos que curso o primeiro ano do ensino médio.
}

Na pergunta se ainda existem brincadeiras só para meninos e outras só para meninas, $49 \%$ responderam que sim, nesse valor os meninos são em maioria representando $50 \%$ das opiniões, reconhecendo o preconceito existente, contra $44 \%$ de meninas e $4 \%$ que não se identificaram como vemos em algumas falas: 
"Depende da brincadeira, mas acho que sim", "Sim, brincadeiras muito violentas, elas não são proibidas, depende da vontade de participar", "Sim, por exemplo, quando o filho homem quer brincar de boneca e o pai impede temendo que ele vire gay".

Diz uma menina de 15 anos, quanta riqueza para ser trabalhada nessa frase, no sentindo de construções de estereótipos que cercam tão firmemente as relações entre os gêneros, desde pequenos. Esse exemplo serve também dentro do âmbito escolar, quanto, por exemplo, a menina se destaca em algum esporte dedicado só a "garotos", logo já é taxada de vários apelidos acerca de sua própria sexualidade.

Já 51\% das respostas diz que não, não há mais brincadeiras só para meninos e outras só para meninas: "Não, porque todas brincadeiras devem ser para todos", "Não, nunca existiu", "Acredito que não, mas tudo depende da brincadeira" ou "Não, mas regras e algumas modificações sim".

Da mesma maneira ocorre em relação aos esportes, a grande maioria acredita que não existam atividades só para meninos ou meninas, porém todos eles frisam a diferença entre os sexos, simbolizando o uso da força, que podem machucar as meninas, aqui voltamos ao discurso do "eterno feminino", como a mulher sendo frágil e delicada, que precisa ser cuidada. Essas ideias inclusive vêm das próprias meninas ao chamarem os garotos de brutos e violentos. Porém alguns defenderam a necessidade dos esportes na aula de educação física não separarem os meninos das meninas, pois "deveria ser um jogo de todos, porque todos merecem aprender algo diferente.".

Na pergunta 16 tentamos identificar como os grupos de meninos e meninas se organizam, interagem e se as relações de gênero transitam naturalmente neste espaço de convivência. Já que para os adolescentes a amizade caracteriza-se fundamentalmente por afeto, divertimento e reciprocidades, mútua consideração, cooperação, manejo eficaz de conflito, benefícios equivalentes em trocas sociais positivas, e gostar um do outro. Portanto, para os adolescentes os círculos de amizade lhe dão o sentimento de pertencimento, proporcionando-lhe um sentido social de grande importância. Vejamos os gráficos: 
Gráfico 6 - Relações de amizade por gênero no grupo das meninas da amostra, 2011

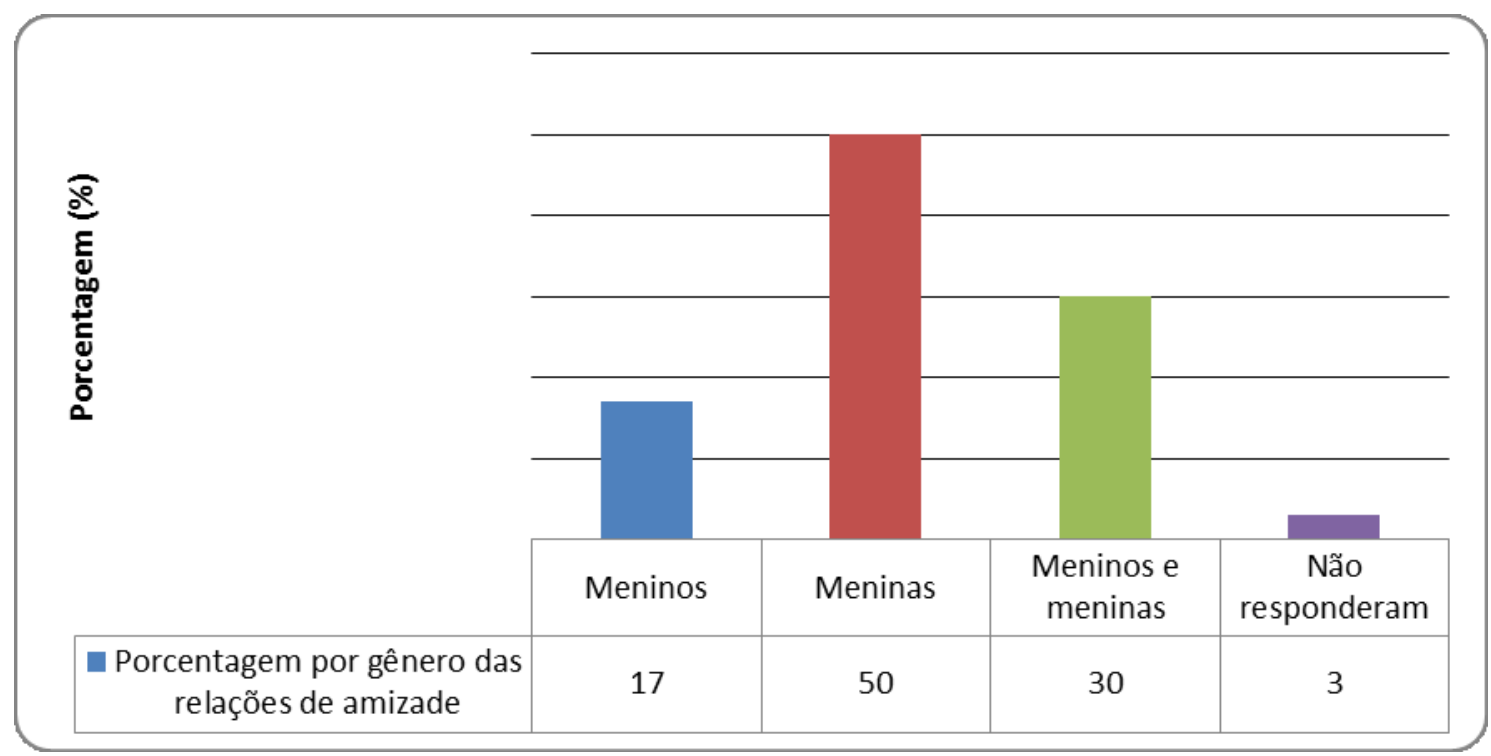

Fonte: Elaboração da autora, a partir do estudo de campo.

Neste gráfico visualizamos a representatividade que os grupos liderados por meninas possuem, desta forma percebemos que em sua grande maioria as relações são de meninas com meninas equivalente a $50 \%$ das respostas; Em seguida com $8 \%$, algumas meninas colocam que em seu grupo de amigos possuem mais meninos do que meninas; Com $30 \%$ verificamos algumas falas que dizem que em seu circulo de amizade tem tanto meninas quanto meninos e isso não faz diferença no estilo de amizade, inclusive desses $30 \%$ encontramos narrativas que incluíram gays e lésbicas. E por fim, somente $3 \%$ não responderam esta pergunta.

Já com os meninos percebemos resultados semelhantes, nos grupos dos meninos, há presença mais de meninos, simbolizando 63\%; Os meninos que dizem ter mais meninas em seu grupo representam $8 \%$ e $27 \%$ ficam para aqueles que possuem amizades tanto com meninas quanto com meninos.

Desta forma, para nossos adolescentes predominam as relações com outros jovens do mesmo gênero, mas possibilitando a relação tanto com menina quanto com menino pelo próprio cotidiano escolar que os ajuda nas trocas de experiências e convívios diários que serão partilhados entre ambos os gêneros. Assim, entendemos que as amizades entre pessoas de sexo oposto têm se tornado mais comuns, deixando de ser consideradas anormais ou com interesses sexuais. Vale ressaltar que em nenhum resposta dos meninos havia narrativas de possíveis amizades entre gays e lésbicas como, por exemplo, ocorreu 
com as meninas, simbolizando que para este grupo masculino pesquisado, ainda há maior resistência em se discutir e quem sabe até mesmo conviver com os homossexuais.

Gráfico 7 - Relações de amizade por gênero no grupo dos meninos da amostra, 2011

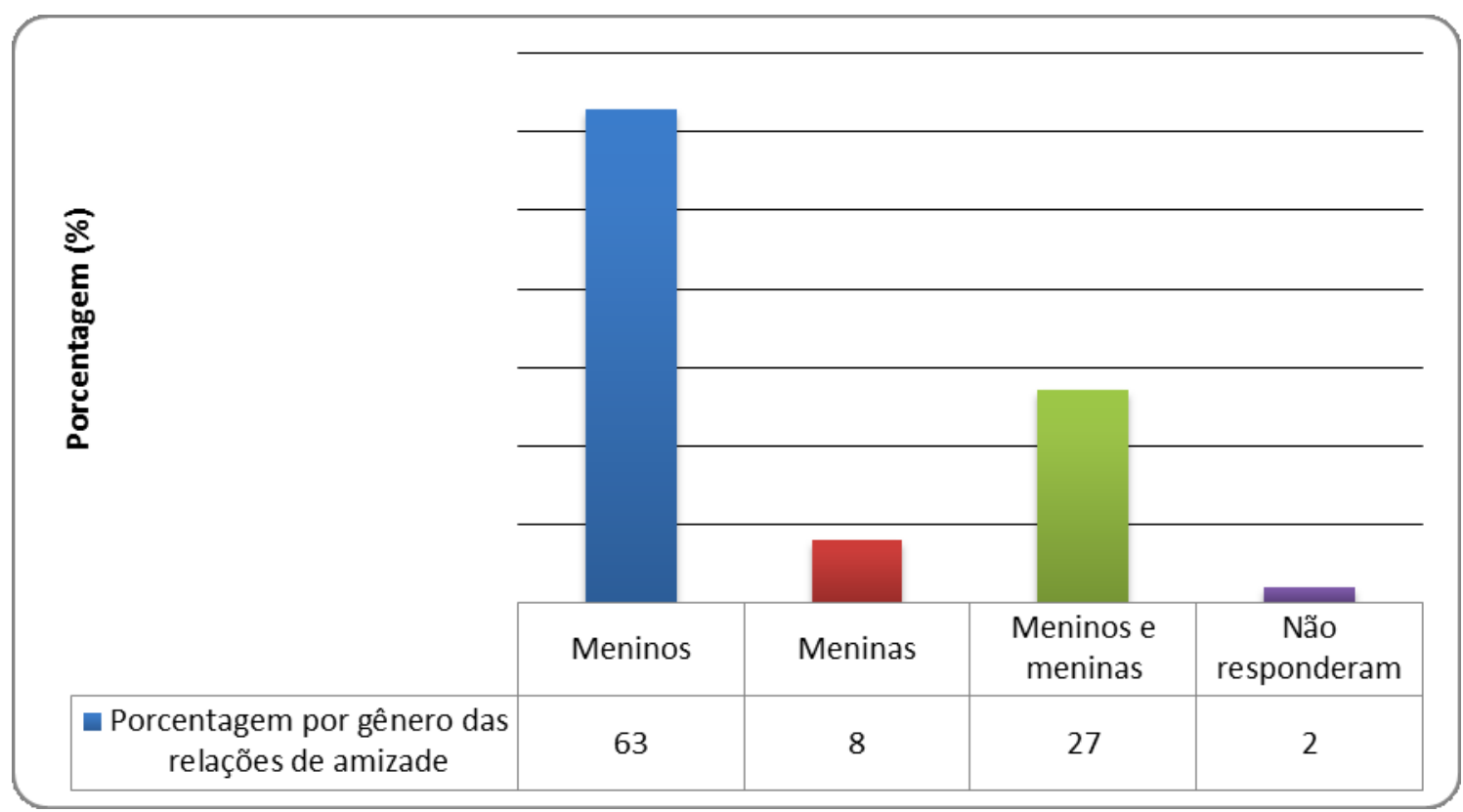

Fonte: Elaboração da autora, a partir do estudo de campo.

Por meio dos questionários aplicados a esses adolescentes podemos perceber as contradições investidas nos discursos desses jovens. Até porque de 87 adolescentes, todos possuem uma educação familiar diferente uns dos outros, possuem uma vida socioeconômica que também os diferem, fruto das desigualdades sociais, crenças, histórias, vivências que os fazem perceber o cotidiano ao seu redor, através de um olhar seletivo. Ou seja, eles vêm da maneira como são condicionados a verem pelas instituições sociais. Porém, alguns que tiveram a oportunidade de serem incentivados a uma criticidade maior, seja através de diálogos familiares ou mesmo por algum professor, conseguem perceber a necessidade de mudanças, como percebemos nesta fala: " $E$ importante termos informações para ajudar quem não tem e também ouvirmos as coisas boas e ruins para escolher a melhor", diz este jovem e 16 anos cursando o primeiro ano do ensino médio.

Na busca por essas mudanças e como elas poderiam acontecer no cotidiano escolar, questionamos aos jovens se eles acreditam que na escola ainda existam algum tipo de preconceito à respeito da sexualidade, para assim mapearmos este tipo de discriminação que os afeta e se os afeta diariamente. 
Nesta pergunta, somente uma menina deixou em branco; $65 \%$ responderam que sim, confirmando a presença do preconceito e em suas narrativas encontramos duas temáticas a respeito do preconceito: virgindade e homossexuais. Os jovens se posicionaram que o preconceito existe porque a "maioria" dos alunos não conseguem lidar com as orientação sexuais por falta de informação e também sobre questões que envolvem a virgindade para as meninas. Como percebemos nessas falas:

\begin{abstract}
"Sim, porque Deus criou o homem e a mulher e nãos os gays", diz um jovem de 15 do primeiro ano do ensino médio; "Sim, mas muito pela religião das pessoas"; "Sim, porque principalmente meninos mais afeminados sofrem com a discriminação", "Sim, preconceito a maioria só por causa que é LGBTT acha que não é gente". "Sim, eu sou um preconceituoso, mas cada um com suas decisões", "Sim, mas os professores não fazem nada", "Sim, porque na escola existem alguns gays e os alunos "a maioria" não gostam e tem vezes que até batem nesses alunos por causa da sexualidade", pontua um menino de 16 anos do segundo ano do ensino médio.
\end{abstract}

Outras foram justificadas como:

"Sim, as pessoas ficam me chamando de gay, viado e vários outros xingamentos"; "Sim, porque eles ficam querendo saber se é virgem ou se sai com mais de um cara, ou porque você não é virgem"; "Sim, porque o homossexualismo ainda não é abordado/encarado de maneira normal pelas pessoas"; "Sim, os gays e lésbicas são maltratados e zuados (sic) só por sua escolha e muitos sofrem violência física"; "Sim, entre os alunos ainda existem e a maioria as vezes é por falta de informação".

Vejamos este quadro: 
Quadro 3 - Tipos de preconceito no cotidiano escolar

\begin{tabular}{|c|l|l|}
\hline $\begin{array}{c}\text { Responderam que há } \\
\text { preconceitos nas escolas }\end{array}$ & Virgindade \\
\hline $\mathbf{5 7}$ questionários: 65\% & $\begin{array}{l}\text { Homossexuais } \\
10 \text { questionários } \\
\text { pontuam sobre o } \\
\text { preconceito contra a } \\
\text { mas justificam colocando apenas } \\
\text { sim. }\end{array}$ & $\begin{array}{l}\text { perda da virgindade ou } \\
\text { adolescentes grávidas } \\
\text { preconceito contra os } \\
\text { homossexuais; }\end{array}$ \\
\hline
\end{tabular}

Fonte: Elaboração da autora, a partir do estudo de campo.

Já aos questionários que negaram a existência do preconceito, estes representam $33 \%$ do total, com justificativas como: "Não, na minha opinião não existe preconceito, os homossexuais tem muito espaço na sociedade", diz este jovem de 15 anos que cursa o primeiro ano do ensino médio; "Acho que não, porque hoje em dia é crime";

Constatamos aqui a importância da educação sexual, do educador presente de maneira efetiva na vida desses jovens, no exercício da libertação dos papeis sociais do feminino e masculino, expressa numa representação social como verdade, saber e conhecimento sexual, a fim de apagar o traçado e fronteiras entre os sexos.

Acreditamos ser extremamente necessário refletirmos sobre quem é nosso aluno, inclusive a respeito de questões de gênero e sexualidade. Como apontam Bill Green e Chris Bigun, está emergindo uma nova geração, com uma constituição radicalmente diferente. $\mathrm{E}$, para esses autores, algumas questões devem ser investigadas como, por exemplo: estão as escolas lidando com estudantes que são fundamentalmente diferentes dos/as de épocas anteriores? E têm as escolas e as autoridades educacionais desenvolvido currículos baseados em pressupostos essencialmente inadequados e mesmo obsoletos sobre a natureza dos/as estudantes? Para os autores, necessário se faz compreender a emergência de um novo tipo de estudante, com novas necessidades e novas capacidades. É preciso antes de qualquer coisa compreender a presente configuração social como uma condição cultural específica: a pós-modernidade - momento em que se descobre que os elementos que sempre foram pensados como sendo componentes invariantes essenciais da experiência humana não são fatos naturais da vida, mas construções sociais (GREEN; BIGUM, 1995).

Ao serem questionados se na disciplina de História alguma vez houve discussões à respeito das relações de gênero e/ou sexualidade, somente $8 \%$ responderam que sim, que 
correspondem a 7 questionários; Inferior aos $92 \%$ que disseram não e correspondem a 80 questionários, conforme vemos no gráfico abaixo:

Gráfico 8 - Discussão sobre Gênero e sexualidade na disciplina de história dos (as) alunos (as) da amostra, 2011

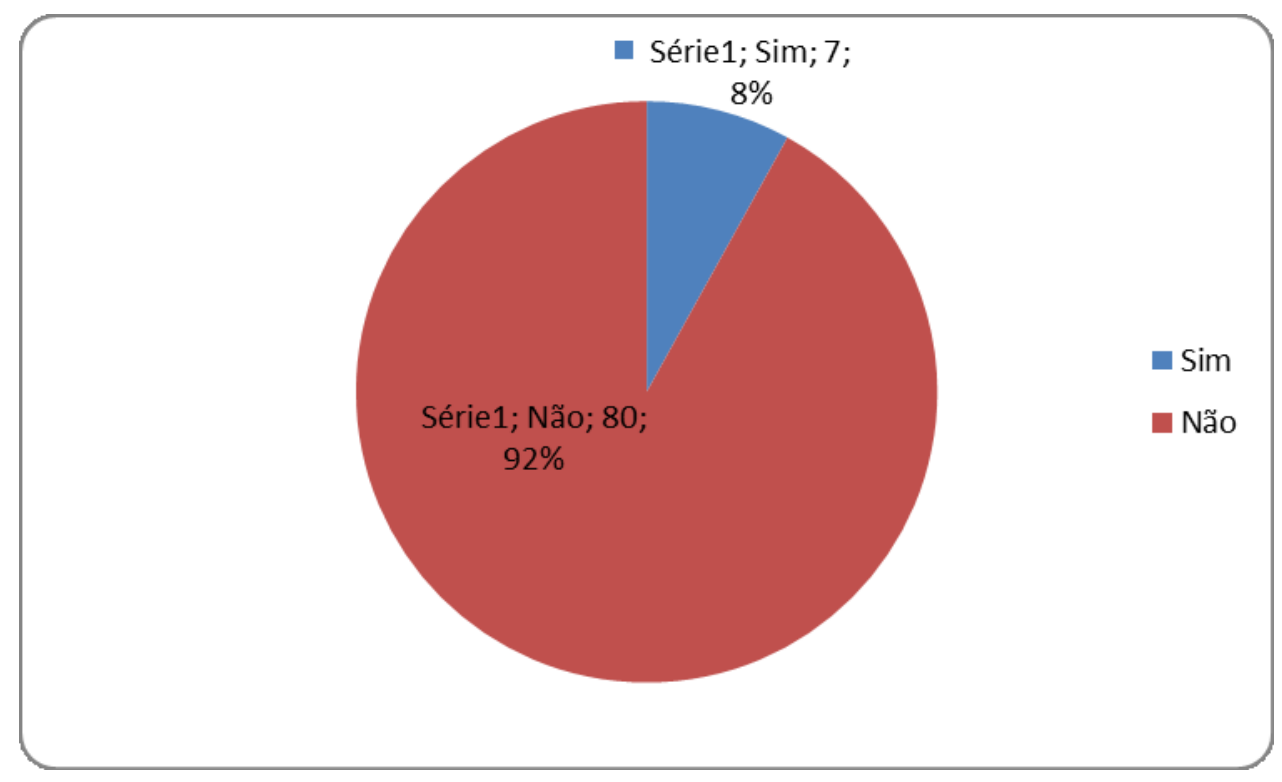

Fonte: Elaboração da autora, a partir do estudo de campo.

Questionados sobre se algum professor já os ajudou a sanar dúvidas referentes à sexualidade, $68 \%$ responderam que sim, encontrando este amparo em algum docente no espaço escolar: 
Gráfico 9 - Dúvidas referente a sexualidade sanadas pelos professores dos (as) alunos(as) da amostra, 2011

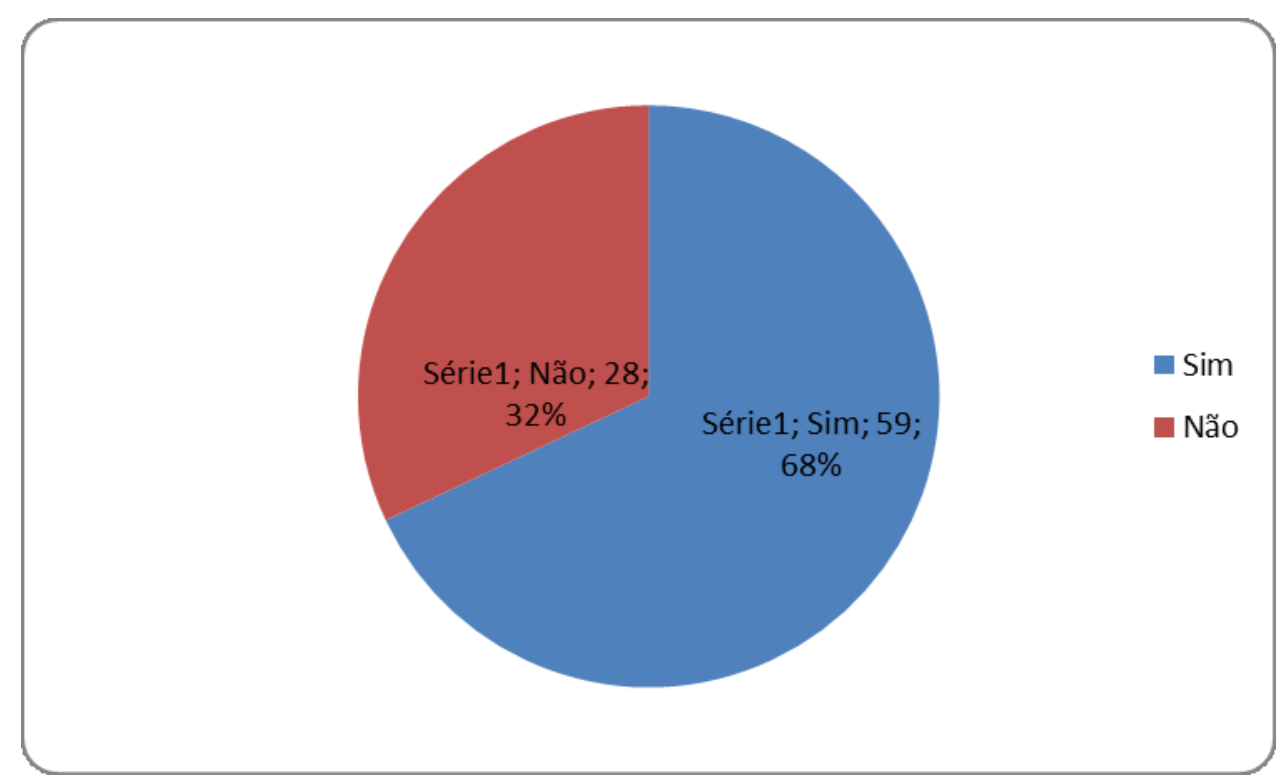

Fonte: Elaboração da autora, a partir do estudo de campo.

Os professores como seres humanos, têm o direito de não sentirem-se à vontade de trabalhar algumas questões que permeiam também, seus próprios valores e religiosidade, por isso a importância de a instituição escolar escolher o professor que queira fazer também esse papel de educador sexual. Mas como educadores, eles precisam ao menos buscar um entendimento do que é essa vivência, de descoberta e sentimentos, não acreditando que irão incentivar ao ato sexual, mas sim ajudando-os, sendo um dos alicerces, a passar por essa fase da vida.

Dentre esses professores que ajudaram os alunos a sanarem suas dúvidas ou aproveitaram um questionamento especifico de algum aluno para trabalhar com o restante da turma, encontramos as disciplinas de ciências, filosofia e sociologia: 
Gráfico 10 - Sexualidade trabalhada nas disciplinas, de acordo com os (as) alunos (as) da amostra, 2011

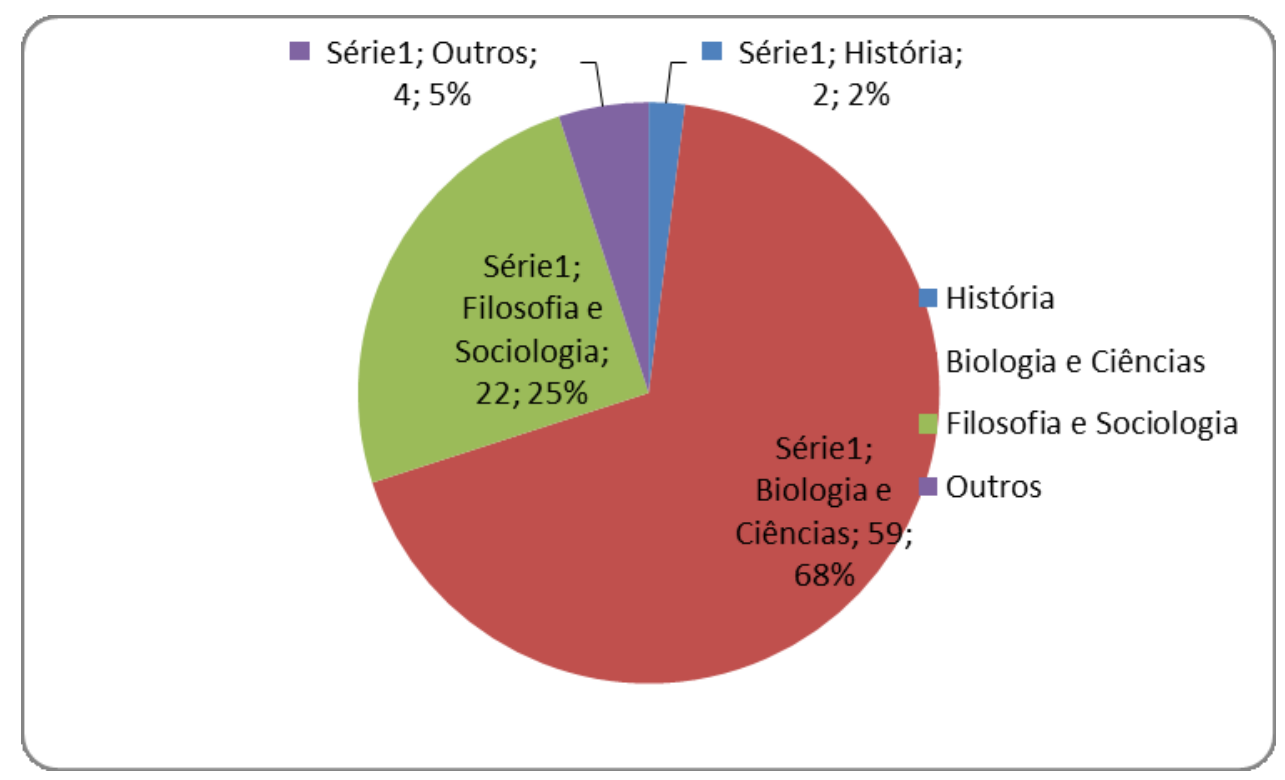

Fonte: Elaboração da autora, a partir do estudo de campo.

A abordagem da Biologia configurou uma dimensão estritamente reprodutiva, acentuada por determinantes genéticos e tornou-se quase incapaz de explicitar, no conceito de sexo, as dimensões existenciais e culturais. Já a concepção de sexualidade que pretendemos assumir na presente pesquisa têm a conotação de uma qualidade humana, que incorpora os componentes biológicos e a variação evolutiva da espécie humana, mas busca atingir significações culturais e existenciais muito mais exigentes.

[...] tudo isso faz da sexualidade humana o que ela pode ser uma descoberta, uma elaboração, uma busca. Um peso que a estrutura como um existencial, corno uma dimensão do ser no mundo do homem, posto que não nos referimos a uma sexualidade animal, sem história e sem cultura, mas à sexualidade enquanto imersa na temporalidade, nela recebendo sua revelação vivencial, suas formalizações conceituais, sua expressão estética, seu tratamento moral e social (VASCONCELOS, 1971, p. 3).

A disciplina de História representa somente $2 \%$ do gráfico e ao serem questionados se a disciplina de História deveria trabalhar questões referentes ao gênero e sexualidade, em sua grande maioria, a resposta não foi representada em cerca de $73 \%$ dos questionários, com justificativas como: 
"Eu acho que não, porque não tem nada haver com a disciplina"; "Não. História somente estuda sobre os antigos tempos"; "Não, a história serve para falar sobre fatos antigos, acho que não entra sexualidade"; "Não, porque história só fala sobre o passado e coisas que aconteceram no mundo"; "Jamais, em hipótese alguma, só em ciências"; "Não, porque eu acho que deveria ter uma matéria só para isso, para discutir essa questão."

Os $21 \%$ restantes correspondem aos adolescentes que acreditam que a disciplina de história poderia incluir discussões sobre gênero e sexualidade, justificando em sua maioria das vezes, que dentro da história o professor poderia abordar questionamentos referentes à sexualidade, como ela era tratada nos períodos antigos, como por exemplo, na antiguidade. Alguns alunos pontuaram:

\footnotetext{
"Sim, porque nós podemos ver como foi no passado a questão da sexualidade e também nos dias de hoje"; "Poderíamos entender o que as pessoas pensavam sobre isso no inicio das primeiras civilizações"; "Acredito que sim, dependendo da atualidade do professor"; "Sim, pois o sexo é uma manifestação essencial para que a vida continue a crescer e a formar novas histórias".
}

Interessante esta última fala, pois esta jovem de 16 anos compara o sexo à procriação para que a partir daí novas histórias e novos sujeitos históricos aconteçam.

Outra narrativa que se desenvolve comparando o sexo com a procriação e a história é: "Sim, porque a sexualidade vem desde do (sic) começo da humanidade, sem procriação não há história"; Ou "Sim, pois a história é para contar história e então é muito bom para contar sobre a história da sexualidade e do gênero".

Disto decorre, portanto, que a sexualidade é uma qualidade essencialmente humana, não podendo ser reduzida ao nível da sexualidade do mundo animal; a sexualidade humana configura uma realidade essencialmente determinante do ser humano. Isto nos impulsiona a investigar as formas pelas quais a sexualidade se constituiu em modelo hegemônico ou tomou contornos específicos em diferentes épocas históricas. Assim, antes de enveredarmos pelo caminho da história, é de fundamental importância compreender melhor o que nos diz Foucault:

Falar da "sexualidade" como uma experiência historicamente singular suporia, também; que se pudesse dispor de instrumentos susceptíveis e analisar, em seu próprio caráter e em suas correlações, os três eixos que a constituem: a formação dos saberes que a ela se referem, os sistemas de poder que regulam sua prática e as formas pelas quais os indivíduos 
podem e devem se 'reconhecer como sujeitos desta sexualidade [...] (FOUCAULT, 1984, p. 11).

Para finalizar, encontramos respostas que diz que discutir questões sobre a sexualidade pode partir de qualquer disciplina, inclusive a história e que vai depender mais do professor do que necessariamente da disciplina: "Sim, qualquer disciplina na minha opinião poderia sair de seu assunto para se referir a sexualidade"; "Sim, qualquer disciplina, basta informarse";

É preciso, então, cada vez mais pensar de forma diferente da que se vem pensando, revendo nossas prioridades, nossos investimentos, nossos compromissos e nossos desejos. É preciso examinar o estudante-sujeito pós-moderno no contexto mais amplo do currículo, levando em conta o cenário educacional e cultural mais amplo existente fora do sistema formal de escolarização, tendo em vista o deslocamento da escola para a mídia eletrônica de massa, especialmente a televisão, o computador e o vídeo, como organizadores ou reorganizadores da ação e do significado humanos. Entre estas questões podemos destacar as discussões sobre gênero e sexualidade e investiga-las tendo em vista esses pressupostos e pensando quem é este nosso aluno torna-se essencial.

Na última questão do questionário, perguntamos se eles aprovam debater questões sobre sexualidade e relações de gênero no ambiente escolar, de forma que $8 \%$ não veem a escola como um ambiente propício para esta discussão: "É errado, a escola deve ensinar e ajudar para um bom emprego ou outras coisas a mais, sexualidade é com a pessoa e a família"; "Bem eu acho que não, porque tem aluno que tem a cabeça fora do lugar"; Para estes alunos discussões sobre sexualidade ainda deveriam estar presos ao ambiente "privado" e familiar.

Aos que não responderam e deixaram a pergunta em branco temos $14 \%$ dos questionários e o restante, $78 \%$ defendem a escola um lugar propício para se debater estas temáticas e trazer aos alunos maiores informações e conhecimentos sobre sua própria sexualidade, como vemos:

"Eu acho isso muito importante, porque nem todos os pais conversam sobre isso, e temos que aprender sobre a sexualidade"; "Acho que é bom, porque a escola tem adolescentes e é no começo da vida que aprendemos, porque quando chegarmos na fase adulta, já vai ter conhecimento"; "Acho bem importante e bem eficaz, porque muitas pessoas não se sentem a vontade em falar com os pais sobre esses tipos de assuntos e procuram falar com os amigos, que nem sempre ajudam a tirar nossa dúvidas. Então seria bom que a escola debatesse esse assunto, assim mais pessoas seriam informados", conclui esta jovem de 15 anos. 
Por fim, percebemos a importância de se dar uma educação sexual aos jovens, como oportunidade de assumirmos uma postura de igualdade e amor entre os seres humanos, uma vez que, sim, acredito que as relações de gênero e a maneira de viver sua sexualidade, não deve ser pautada em hierarquias de poder, mas no amor e na sensibilidade de ver o "outro" como parte de si mesmo.

\title{
Considerações Finais
}

\begin{abstract}
Aprendemos a viver o gênero e a sexualidade na cultura, através dos discursos repetidos da mídia, da igreja, da ciência e das leis e também, contemporaneamente, através dos discursos dos movimentos sociais e dos múltiplos dispositivos tecnológicos. As muitas formas de experimentar prazeres e desejos, de dar e de receber afeto, de amar e de ser amada/o são ensaiadas e ensinadas na cultura, são diferentes de uma cultura para outra, de uma época ou de uma geração para outra. E hoje, mais do que nunca, essas formas são múltiplas. As possibilidades de viver os gêneros e as sexualidades ampliaram-se. As certezas acabaram. Tudo isso pode ser fascinante, rico e também desestabilizador.

Louro (2003).
\end{abstract}

O Brasil tem conquistado importantes resultados na ampliação do acesso e no exercício dos direitos, por parte de seus cidadãos. No entanto, há ainda imensos desafios a vencer, quer do ponto de vista objetivo, como a ampliação do acesso à educação básica e de nível médio, assim como do ponto de vista subjetivo, como o respeito e a valorização da diversidade. As discriminações de gênero, étnico-racial e por orientação sexual, como também a violência homofóbica, são produzidas e reproduzidas em todos os espaços da vida social.

Quando tivemos contato com as narrativas dos alunos que compõem a fonte documental para o desenvolvimento deste trabalho, pudemos identificar a escola como um ambiente que ainda reflete o sexismo que perpassa toda a sociedade, reproduzindo, com frequência, as estruturas sociais; reforçando os preconceitos e privilégios de um sexo sobre o outro.

A escola pode transformar-se em um lugar privilegiado para a promoção da igualdade de gênero e das orientações sexuais, oferecendo muitas possibilidades de debates sobre o tema. A inclusão da perspectiva de gênero e sexualidade no cotidiano escolar não pode ser eventual nem se limitar aos perigos, às doenças, à gravidez indesejada. Devemos envolver o coletivo de professores para que as estratégias sejam duráveis e sustentáveis e não, apenas 
ações restritas de alguns professores durante determinado período de tempo, nem de projetos isolados e de curta duração.

É no ambiente escolar que os/as estudantes podem construir suas identidades individuais e de grupo, podem exercitar o direito e o respeito à diferença. As reflexões que fizemos até aqui e que propomos nesta dissertação pretendem desvelar o currículo oculto que, ao excluir as diversidades de gênero, étnico-racial e de orientação sexual, entre outras, legitima as desigualdades e as violências decorrentes delas. Propomos que educadores e educadoras observem o espaço escolar, quem o compõe, as relações que se estabelecem nesse espaço, quem tem voz e quem não tem, os materiais didáticos adotados nas diferentes áreas do conhecimento, as imagens impressas nas paredes das salas de aula, enfim, como a diversidade está representada, como e o quanto é valorizada.

Devemos nos ater ao fato de que ao estudar e discutir a sexualidade humana, na finalidade de compreender sua dinâmica no campo da sociedade e da construção histórica entre suas múltiplas possibilidades, cremos que deve ser investigada em bases reais, como, por exemplo, as presentes nas narrativas dos alunos. $O$ pensamento dialético pretende abarcar a questão da sexualidade, não de maneira linear e evolucionista, mas sim tende a compreender as coisas pelas suas contradições externas e internas, com seus vínculos e formas próprias de se darem a conhecer.

A partir desta e de outras considerações, esperamos que professoras, professores e demais profissionais da educação fortaleçam o papel que exercem de promotores/as da cultura, de respeito à garantia dos direitos humanos, da equidade étnico-racial, de gênero e da valorização da diversidade. Desta forma contribuindo para que a escola não seja um instrumento da reprodução de preconceitos, mas seja espaço de promoção e valorização das diversidades que enriquecem a sociedade.

Devemos abraçar a urgência por uma escola que seja livre de preconceitos, onde todos possam se expressar e se desenvolver plenamente, exercitando a capacidade de aceitação e compreensão das diferenças. Esse é o princípio do respeito à diversidade. O princípio de uma sociedade sem discriminações sociais e sexuais. O princípio da liberdade do ser humano.

Indiferente a qualquer outra dimensão social em que os sujeitos se constituem, a escola é um local demarcado por inúmeras vivências das sexualidades e diversas formas de construção do gênero, sendo a negação dessa afirmativa um dos grandes obstáculos que temos que enfrentar como profissionais e pesquisadores/as da educação.

Concluindo, o ambiente escolar e o ensino de história deveriam ter como papel fundamental se constituir em espaços que possam promover uma educação menos desigual, mais humanizadora e que potencialize as habilidades humanas, até mesmo no modo de ver 
que há diferenças. Mas também reconhecer nelas e através delas as qualidades, vislumbres, edificações e dimensões que nos fazem grandes seres humanos. Únicos. Originais. Profundos.

\section{Referências}

ALEGRO, Regina Célia. Conhecimento prévio e aprendizagem significativa de conceitos historicos no ensino medio. 2008. 239 f. Tese (Doutorado em Educação) - UNESP, Marilia, 2008.

CANO, M. A. T.; FERRIANI, M. G. C. Sexualidade na adolescência: um estudo bibliográfico. Revista Latino Americana de Enfermagem, Ribeirão Preto, v. 8, n. 2, p. 18-24, abr. 2000.

DINIS, Nilson Fernandes. Educação, relações de gênero e diversidade sexual. Educação e Sociedade, Campinas, v. 29, n. 103, p. 477-492, maio/ago. 2008. Disponível em: <www.cedes.unicamp.br >. Acesso em: 5 out. 2013.

FIGUEIRÓ, Mary Neide Damico. Educação sexual: como ensinar no espaço da escola. In: CONGRESSO DE EDUCAÇÃO INCLUSIVA, 1., 2003, São Paulo. Anais....São Paulo, 2003.

FOUCAULT, Michael. A ordem do discurso. Aula inaugural no Collège de France, pronunciada em 2 de dezembro de 1970. Tradução de Laura Fraga de Almeida Sampaio. São Paulo: Loyola, 2002.

FOUCAULT, Michael. História da sexualidade. Rio de Janeiro: Ed. Graal, 1984.

FRANÇA, Cyntia Simioni. Possibilidades e limites na construção do conhecimento historico escolar em conexão com o mundo virtual. 2009. 152 f. Dissertação (Mestrado emm História Social) - Universidade Estadual de Londrina, Londrina, 2009.

FREIRE, Paulo. Pedagogia do oprimido. Rio de Janeiro: Paz e Terra, 2005.

GREEN, Bill; BIGUM, Chris. "Alienígenas em sala de aula" In: SILVA, Tomaz T. (Org.). Alienígenas na sala de aula. Petrópolis: Vozes, 1995. p. 206-43.

HOBSBAWM, Eric. A volta da narrativa. In: STONE, Lawrence. Sobre História. São Paulo: Cia. das Letras, 1998.

KNOBEL, M. Orientação familiar. Campinas: Papirus, 1992.

LOURO, Guacira Lopes. Corpos que escapam. Estudos Feministas, Brasília, v. 4, 2003. 
LOURO, Guacira Lopes. O corpo educado: pedagogias da sexualidade. Belo Horizonte: Autêntica, 1999.

MELLO, Maria do Céu de. O conhecimento tácito substantivo dos alunos: no rasto da escravatura. In: BARCA, Isabel (Org.). Perspectivas em educação histórica. Minho: Universidade do Minho, 2001. p. 157.

PARANÁ. Lei $n^{\circ} 15.826$, de 1 de maio de 2008. Fixa, a partir de $1^{\circ}$ de maio de 2008 , valores do piso salarial no Estado do Paraná, com fundamento no inciso V, do artigo $7^{\circ}$, da Constituição Federal e na Lei Complementar Federal $\mathrm{n}^{\circ}$ 103, de 14 de julho de 2000. Disponível em: <http://www.normaslegais.com.br/legislacao/leipr15826_2008.htm>. Acesso em: 5 out. 2013.

PARANÁ. Secretária da Educação. Colégio Estadual Antônio Raminelli. Disponível em:<http://www.cabantonioraminelli.seed.pr.gov.br/modules/noticias/article.php? storyid=3>. Acesso em: 20 fev. 2012.

PARANÁ. Secretária da Educação. Programas e Projetos. Disponível em: $<$ http://www.gestaoescolar.diaadia.pr.gov.br/modules/conteudo/conteudo.php? conteudo $=80>$. Acesso em: 20 fev. 2013.

PARKER, R.G. Corpos, prazeres e paixões: a cultura sexual no Brasil contemporâneo. São Paulo: Best Seller, 1991.

PEREIRA, Kely Cristina. Genero e Sexualidade: Os Docentes e a Educação Sexual. In: Simpósio Gênero e Indicadores da Educação Superior Brasileira, Brasília - DF, 6 e 7 de Dezembro de 2007. Dilvo Ristoff (Org.) - Instituto Nacional de Estudos e Pesquisas Educacionais Anísio Teixeira,2007. pp.85-103.

BURKE, Peter. A Escola dos Annales: 1929-1989. São Paulo: Ed. UNESP, 1991.

STONE, L. O Ressurgimento da Narrativa: reflexões sobre uma nova velha história. Revista História, Campinas, n.2/3, p. 19-23, 1991.

VASCONCELOS, Naumi. Os dogmatismo sexuais. Rio de Janeiro: Paz e Terra, 1971.

WEREBE, Maria José Garcia. Sexualidade, política e educação. Campinas: Autores Associados, 1998. 